\title{
Thermooxidative Ageing Of Polydicyclopentadiene In Glassy State
}

\author{
Emmanuel Richaud $^{\mathrm{a}, *}$, Pierre Yves Le Gac ${ }^{\mathrm{b}}$, Jacques Verdu ${ }^{\mathrm{a}}$ \\ ${ }^{a}$ Arts et Métiers ParisTech, CNRS, PIMM UMR 8006, 151 bd de l'Hôpital, 75013 PARIS, FRANCE. \\ ${ }^{b}$ IFREMER Centre de Bretagne, Marine Structures Laboratory, BP70, 29280 PLOUZANE, FRANCE. \\ *: Corresponding author : Emmanuel Richaud, email address : emmanuel.richaud@ensam.eu
}

\begin{abstract}
:
Thermal ageing of thin films of unstabilized polydicyclopentadiene (pDCPD) at several temperatures ranging from 120 to $30^{\circ} \mathrm{C}$ was investigated by means of carbonyl build up by FTIR with ammonia derivatization, double bond titration, mass uptake measurement, hydroperoxides titration by iodometry and DSC coupled with sulfur dioxide treatment. In the temperature range under investigation, pDCPD is in glassy state and it oxidizes faster than common polymers oxidized at rubbery state (e.g. polydienic elastomers). Using the kinetic analysis, these results were ascribed to increased initiation rate due to catalyst residues, some possible intramolecular processes favoring propagation, or a very low termination rate of oxidation radical chains because of the control of termination reactions by macroradical diffusion.
\end{abstract}

Keywords : Polydicyclopentadiene ; thermal oxidation ; kinetics ; molecular mobility 


\section{INTRODUCTION}

Most of the knowledge on polymer oxidation mechanisms and kinetics was obtained from experimental studies on elastomers $[1,2]$ or semi-crystalline polyolefins $[3,4]$. The oxidation of all these materials occurs in a rubbery/liquid phase characterized by relatively fast cooperative segmental motions. However, some authors $[5,6]$ have assumed that bimolecular processes between macromolecular reactive species may be disadvantaged because of low diffusivity of these species in such highly viscous matrices. In other words, radical propagation of the oxidation process would not be limited by bimolecular termination processes. It was actually observed that the ratio $\mathrm{k}_{\mathrm{p}}{ }^{2} / \mathrm{k}_{\mathrm{t}}$ expressing oxidizability was higher for PP than for its model compounds [7]. A possible explanation is that rate constant propagation $k_{p}$ has same value in polypropylene (PP) and its liquid model compounds whereas termination constant $k_{t}$ is higher in liquids than in PP amorphous phase. Propagation actually involves a reaction between a peroxy radical and a close monomer unit and so should not be controlled by diffusion whereas termination involves a reaction between two species (peroxy radicals) at low concentration and may be controlled by diffusion so that its rate depends sharply of the medium viscosity.

In the case of polymers in glassy state, extremely low termination rates and then extremely high oxidation rates are thus expected. Unfortunately, kinetic studies of the oxidation of glassy polymers are scarce. In the case of aromatic polymers [8], significant oxidized layer (100 $\mu \mathrm{m})$ were observed despite a slow propagation (linked to strong $\mathrm{C}-\mathrm{H}$ bonds), which militates in favor of termination control by diffusion. A comparison of hydrocarbon elastomers oxidation in rubbery state with oxidation of hydrocarbon glassy polymers at the same temperature would bring another evidence of the molecular mobility effect on oxidizability. This is the reason why pDCPD has been chosen here.

pDCPD is synthetized from Ring Opening Metathesis Polymerization of dicyclopentadiene: 

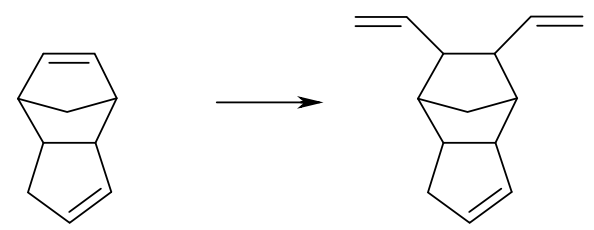

After thermal crosslinking $[9,10,11]$, it gives a network with a glass transition temperature of c.a. $160^{\circ} \mathrm{C}$ used for instance in off-shore applications [12]. Apart some irregularities [9-11], its structure displays highly reactive groups: double bonds able to react by addition reactions and easily abstractable allylic hydrogens.

The present study is limited to unstabilized pDCPD thin films (not submitted to Diffusion Limited Oxidation), i.e. materials not aimed at any industrial purpose, exposed to temperatures ranging from 30 to $120^{\circ} \mathrm{C}$ to illustrate the specificity of oxidation in glassy state. 


\section{EXPERIMENTAL}

\section{Material}

Samples were supplied as stabilized bulk material prepared by casting dicyclopentadiene into an aluminium mould preheated at $40^{\circ} \mathrm{C}$. The catalyst of the metathesis polymerization is a ruthenium salicylaldimine phenylindenylidene complex. Material was cut in 20-30 $\mu \mathrm{m}$ slices using a ReichertJung microtome. These ones were purified by refluxing in $\mathrm{CH}_{2} \mathrm{Cl}_{2}$ overnight. Unstabilized samples were stored in fridge prior to exposure.

2. Exposure conditions

Samples were exposed in ventilated ovens at various temperatures ranging from 120 to $30^{\circ} \mathrm{C}$.

3. Characterization

\subsection{Fourier Transform InfraRed spectroscopy}

FTIR spectra in transmission mode were obtained on free standing films in transmission mode by averaging 4 scans at a $2 \mathrm{~cm}^{-1}$ resolution using a Frontier apparatus (Perkin Elmer) driven by Spectrum software. 


\section{2. $\mathrm{SO}_{2}$ treatment}

Sulfur dioxide treatments were performed by putting samples during $24 \mathrm{~h}$ in closed vessels in which $\mathrm{SO}_{2}$ was in situ generated from solutions of $40 \mathrm{mg}$ of $\mathrm{Na}_{2} \mathrm{SO}_{3}$ ( $\mathrm{S} 0505$ grade - Sigma Aldrich) in $\mathrm{HCl}$ (analysis grade $37 \%$ - Carlo Erba) [13].

\section{3. $\mathrm{NH}_{3}$ treatment}

$\mathrm{NH}_{3}$ treatments were performed by putting samples during $24 \mathrm{~h}$ in closed vessels in which $\mathrm{NH}_{3}$ was in situ generated by combining equimolar solutions of $\mathrm{NH}_{4} \mathrm{Cl}$ and $\mathrm{NaOH}[8]$.

\section{4. lodometry}

Hydroperoxides react with iodine anions in isopropanol using acetic acid for acidizing the media by the following reaction $[14,15,16]$ :

$$
\begin{aligned}
& \mathrm{POOH}+2 \mathrm{I}^{-}+2 \mathrm{H}^{+} \rightarrow \mathrm{POH}+\mathrm{I}_{2}+\mathrm{H}_{2} \mathrm{O} \\
& \mathrm{I}_{2}+\mathrm{I}^{-} \rightarrow \mathrm{I}_{3}^{-}
\end{aligned}
$$

A mass $\mathrm{m}$ (about $1 \mathrm{mg}$ ) of oxidized pDCPD was placed in $7 \mathrm{ml} \mathrm{10:1} \mathrm{isopropanol:acetic} \mathrm{acid} \mathrm{mixture} \mathrm{in}$ a bicol flask (isopropanol: ref 34959 HPLC grade purity 99.9\% - Sigma Aldrich, acetic acid: ref A6283 purity $>99 \%$ - Sigma Aldrich). When the mixture reached refluxing temperature, I' was brought by adding $3 \mathrm{ml}$ of a saturated solution of Nal (ref 409286 - Sigma Aldrich) saturated solution in isopropanol. After a 10 minutes reaction time, solution was analyzed by UV spectroscopy (Perkin Elmer Lambda 35) in $1 \mathrm{~cm}$ UV cell. Hydroperoxides concentration was thus calculated from the $\mathrm{I}_{3}^{-}$ absorbance at $355 \mathrm{~nm}\left(\mathrm{DO}_{355}\right)$ using a molar absorptivity $\varepsilon=25000 \mathrm{I} \mathrm{mol}^{-1} \mathrm{~cm}^{-1}$ by the formula: 


$$
[\mathrm{POOH}]=0.4 \times \frac{\mathrm{DO}_{355}}{\mathrm{~m}}
$$

$[\mathrm{POOH}]$ being here expressed in $\mathrm{mol} \mathrm{kg}^{-1}$ and $\mathrm{m}$ in $\mathrm{mg}$.

\subsection{DSC}

Thermal analysis was performed using a Q10 DSC apparatus (TA Instrument) driven by Q Series Explorer software. DSC was first calibrated with an indium standard. Approximately $1 \mathrm{mg}$ of virgin or oxidized sample was heated from 25 to $300^{\circ} \mathrm{C}$ in sealed aluminum pans, at a heating rate of $10^{\circ} \mathrm{C} \mathrm{min}$ ${ }^{1}$ under an inert atmosphere obtained by purging cell with a $50 \mathrm{ml} \mathrm{min}^{-1}$ nitrogen flow. Results were processed using the TA Analysis software.

\subsection{ThermoGravimetric Analysis}

Gravimetric measurements were monitored using a TGA Q50 (TA Instrument) driven by Q Series Explorer. About $10 \mathrm{mg}$ samples were placed in a Platinum pan which first heated under nitrogen till to the measurement temperature at which cell atmosphere was switched to oxygen or nitrogenoxygen mixtures (GasMix). Results were processed using TA Analysis software. 


\section{RESULTS}

1. Gravimetric study

Mass variation has been monitored for samples exposed at $120^{\circ} \mathrm{C}$ under $21,50,75$ and $100 \%$ of the atmospheric pressure (Figure 1).

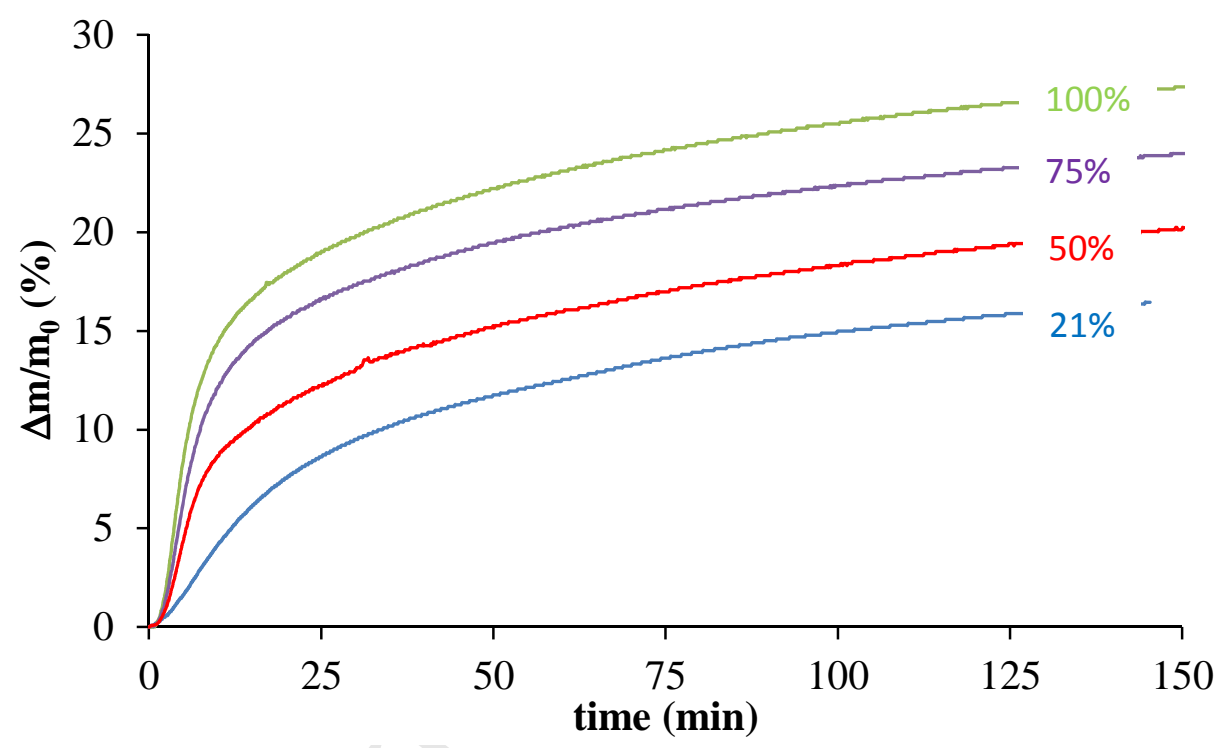

Figure 1. Kinetics of mass uptake at $120^{\circ} \mathrm{C}$ for pDCPD under several oxygen concentrations.

The mass increases continuously which is a characteristic of unsaturated polymers $[1,2,17]$. The rate of mass gain is maximal shortly (1-2 min) after the beginning of exposure, and then decreases continuously.

It is possible to distinguish two periods corresponding to distinct phases of the oxidation process :

- An "initial" period, with a characteristic time of the order of 10-20 min decreasing with oxygen pressure. 
- A "final" period with a characteristic time at least 10 times higher than "initial" one. The mass gain reaches about $10-15 \%$ at the end of the first period that corresponds to $1 \pm 0.2$ oxygen atoms per initial monomer unit.

Maximum rates are almost proportional to oxygen pressure (Table 1) which will be exploited in the "DISCUSSION" section.

\begin{tabular}{|c|c|c|}
\hline Relative pressure & Maximum rate $(\% /$ min) & Ratio rate/pressure \\
\hline 100 & 3.8 & 0.038 \\
\hline 75 & 2.8 & 0.037 \\
\hline 50 & 2 & 0.04 \\
\hline 21 & 0.7 & 0.028 \\
\hline
\end{tabular}

Table 1. Maximum rate of mass uptake at $120^{\circ} \mathrm{C}$.

According to Table 2, pDCPD oxidizes faster and in a relatively greater extent than polybutadiene and polyisoprene, whereas the double bond concentration is $17 \mathrm{~mol} \mathrm{I}^{-1}$ [17] for polybutadiene and $27 \mathrm{~mol}$ $\mathrm{I}^{-1}$ for polyisoprene [2] versus $10 \mathrm{~mol}^{-1}$ in $\mathrm{pDCPD}$ (from its theoretical structure, and even less as it will be seen below).

\begin{tabular}{|c|c|c|c|c|c|c|c|c|c|c|c|c|}
\hline \multirow[b]{2}{*}{$\mathrm{T}\left({ }^{\circ} \mathrm{C}\right)$} & \multicolumn{4}{|c|}{ BR } & \multicolumn{4}{|c|}{ IR } & \multicolumn{4}{|c|}{ PCPD } \\
\hline & $t_{i}(\min )$ & $t_{p}(\min )$ & $\Delta \mathrm{m} / \mathrm{m}_{0} \max$ & $\mathbf{N}$ & $t_{i}(\min )$ & $t_{p}(\min )$ & $\Delta \mathrm{m} / \mathrm{m}_{0} \max$ & $\mathbf{N}$ & $t_{i}(\min )$ & $t_{p}(\min )$ & $\Delta \mathrm{m} / \mathrm{m}_{0} \max$ & $\mathbf{N}$ \\
\hline 55 & & & & & & & & & 120 & 720 & $>0.25$ & $>2.06$ \\
\hline 60 & 5000 & 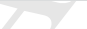 & & & & & & & & & & \\
\hline 80 & 1000 & & & & 240 & 2400 & 0.035 & 0.15 & 30 & 80 & 0.25 & 2.06 \\
\hline 90 & & y & & & & & & & & & & \\
\hline 100 & 200 & 300 & 0.14 & 0.47 & 60 & 900 & 0.015 & 0.06 & & & & \\
\hline 120 & 30 & & & & & & & & 2 & 30 & 0.15 & 1.24 \\
\hline
\end{tabular}

Table 2. Induction time (for carbonyl build up or mass uptake) $t_{i}$, time to plateau $\left(t_{p}\right)$, maximal mass uptake value and number of oxygen atoms grafted per monomer unit $\mathrm{N}$ for polybutadiene [17], polyisoprene [2] and pDCPD (this work). 
2. Changes in molecular structure

The DSC traces of oxidized samples reveal the growth of an exotherm centered at c.a. $150^{\circ} \mathrm{C}$ which disappears upon treatment by sulfur dioxide (Figure 2).

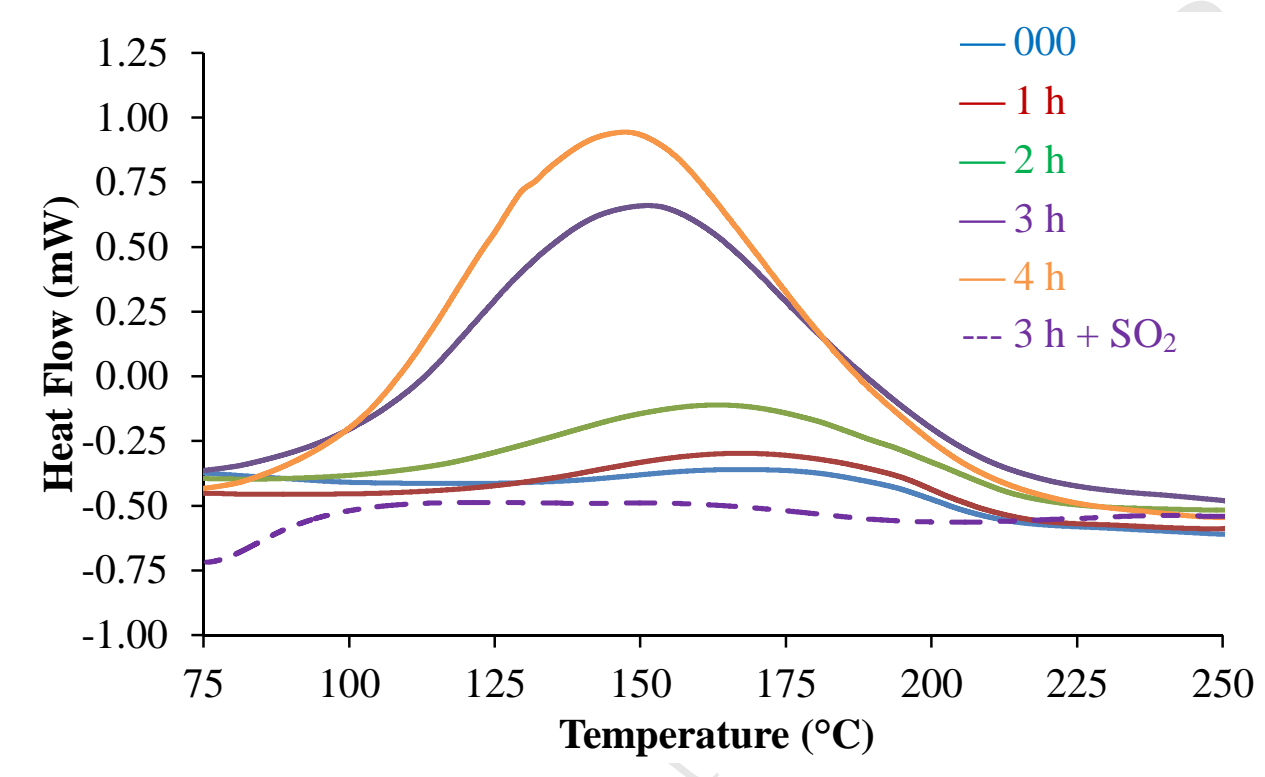

Figure 2. DSC thermograms before (full line) and after (dashed line) $\mathrm{SO}_{2}$ treatment for pDCPD exposed at $55^{\circ} \mathrm{C}$ under air.

The corresponding enthalpy is hence attributed to exothermic processes (mainly bimolecular radical terminations) accompanying $\mathrm{POOH}$ decomposition. It is actually sharply correlated to [POOH] concentration determined from iodometry measurements (Figure 3a). The ratio of $[\mathrm{POOH}]$ values over enthalpy measured by DSC gives a value for the molar enthalpy $\Delta \mathrm{H}_{\mathrm{POOH}}=440 \mathrm{~kJ} \mathrm{~mol}^{-1}$ in agreement with calculations given in [12] using here values for unsaturated substrates [18].

Hydroperoxide concentrations are plotted together with concentrations in carbonyls and double bonds (Figure 3). 


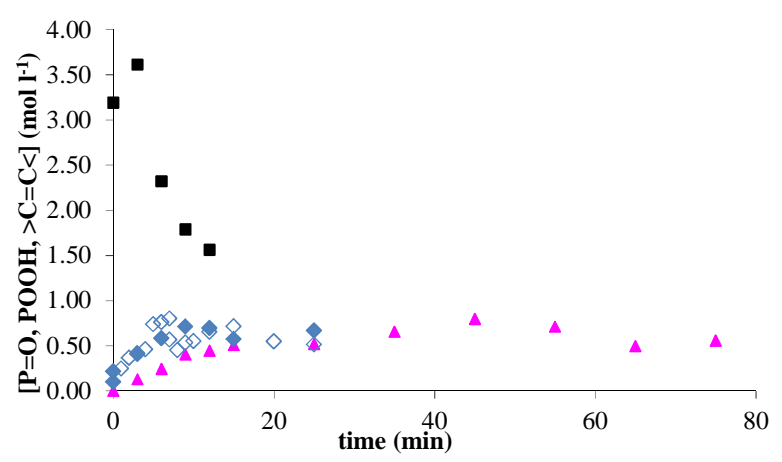

(a)

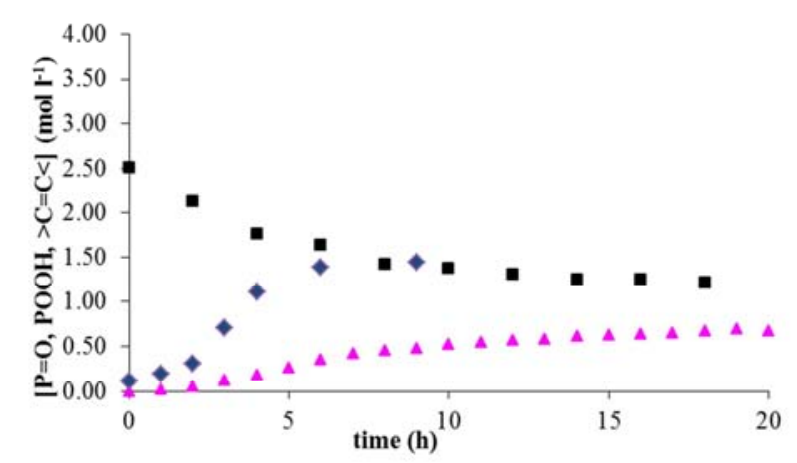

(c)

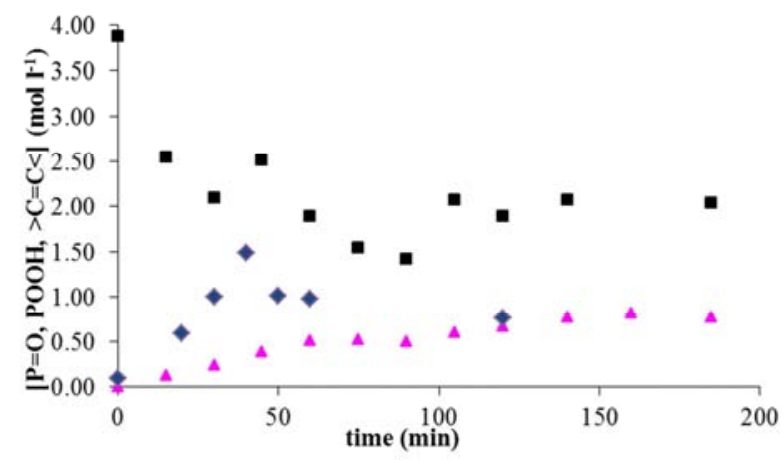

(b)

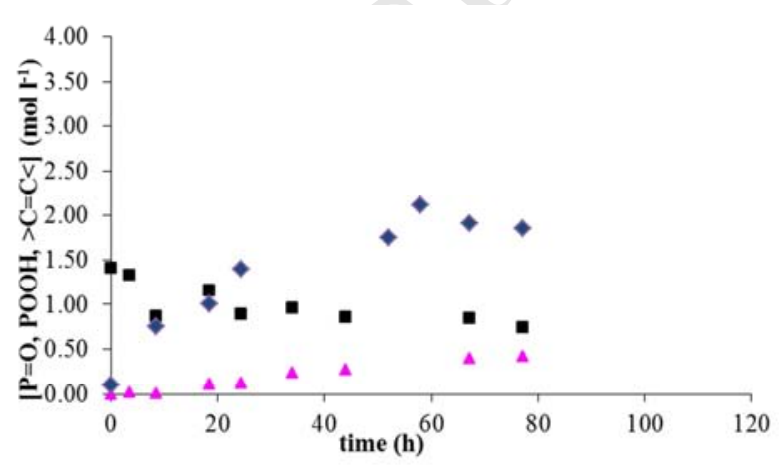

(d)

Figure 3. Changes in hydroperoxides $(\bullet)$, carbonyl $(\boldsymbol{A})$, double bonds $(\boldsymbol{\square})$ for exposures at $120(\mathrm{a})$, 90 (b), 55 (c) and $30^{\circ} \mathrm{C}$ (d). In Figure 3a, open diamonds correspond to iodometric titration of $\mathrm{POOH}$ and close ones to $\mathrm{POOH}$ titration by DSC using $\Delta \mathrm{H}_{\mathrm{POOH}}=440 \mathrm{~kJ} \mathrm{~mol}^{-1}$.

For example, the $\mathrm{POOH}$ concentration at $120^{\circ} \mathrm{C}$ increases rapidly in the previously defined "initial" period to reach a value of about $0.8 \mathrm{~mol} \mathrm{I}^{-1}$ after $10 \mathrm{~min}$ of exposure. At this time, the number of moles of dioxygen absorbed by the polymer is of the same order (Figure 1) which means that oxidation gives almost exclusively hydroperoxides in the "initial" period. After a maxima corresponding to steady state, the $\mathrm{POOH}$ concentration decreases because of the substrate consumption [4]. 
According to simple kinetic models $[4,19]$, the steady state $\mathrm{POOH}$ concentration under oxygen excess is given by:

$$
[\mathrm{POOH}]_{\max }=\frac{1}{\delta}\left(\frac{\mathrm{k}_{3}^{2}[\mathrm{PH}]^{2}}{\mathrm{k}_{1} \mathrm{k}_{6}}\right)^{1 / \delta}
$$

Where $\delta=1$ or 2 is the molecularity of the $\mathrm{POOH}$ decomposition and $\mathrm{k}_{1}$ is the rate constant of $\mathrm{POOH}$ decomposition (denoted respectively by $\mathrm{k}_{1 \mathrm{u}}$ or $\mathrm{k}_{1 \mathrm{~b}}$ in the case of uni- or bimolecular decomposition). $[\mathrm{POOH}]_{\max }$ is thus expected to obey Arrhenius law with an apparent activation energy:

$$
E_{P O O H}=\frac{2}{\delta} E_{3}-\frac{1}{\delta}\left(E_{1}+E_{6}\right)
$$

Where $E_{3}, E_{1}$ (being $E_{1 u}$ or $E_{1 b}$ in the case of uni- or bimolecular decomposition) and $E_{6}$ are the respective activation energies of propagation, initiation and termination.

$[\mathrm{POOH}]_{\max }$ values have been compared with polypropylene data $[4]$ (Figure 4). $[\mathrm{POOH}]_{\max }$ actually obeys Arrhenius' law. Even if PP and PDCPD straight-lines are close, it would be premature to conclude that $\mathrm{POOH}$ decomposition mechanisms are the same (see "DISCUSSION"). 


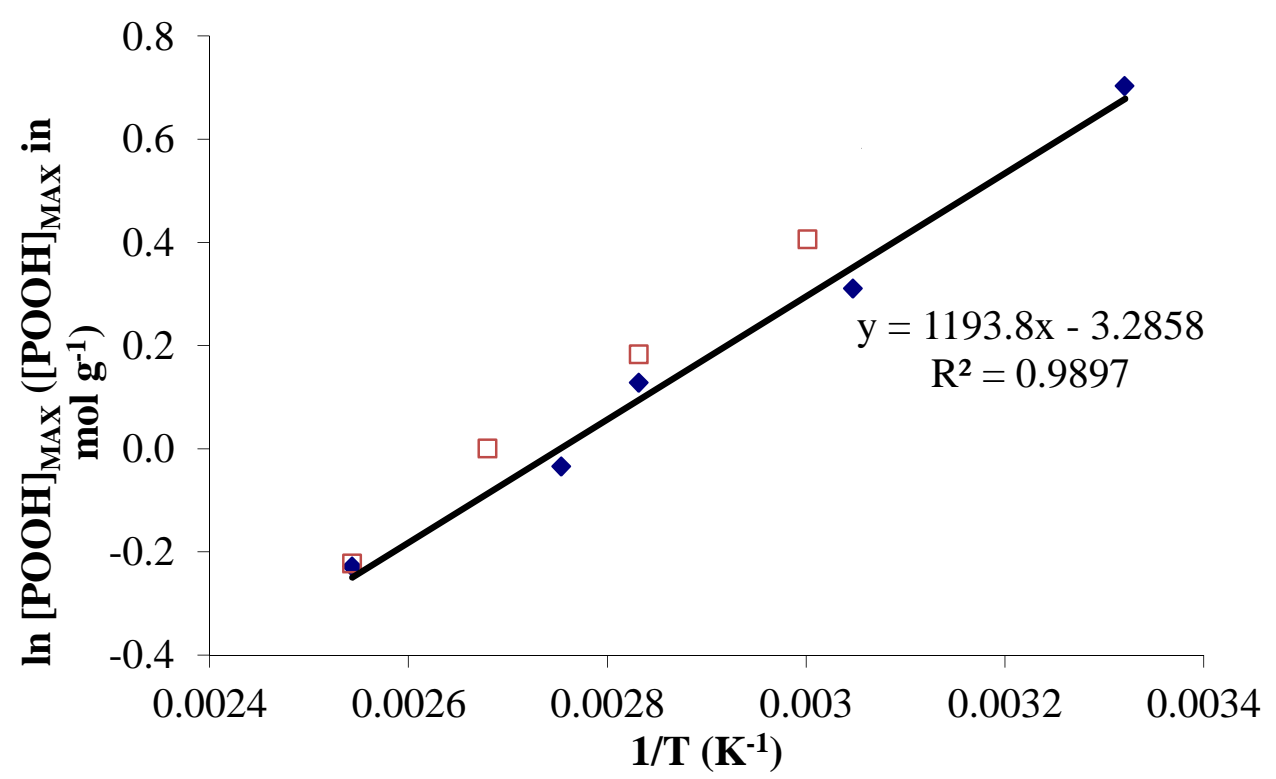

Figure 4. Arrhenius diagram of POOH decomposition enthalpy for PDCPD under air ( $\bullet$ ), and PP under oxygen excess ( $\square)$.

Double bonds absorb at $965 \mathrm{~cm}^{-1}$ (molar absorptivity range from 100 [20] to 168 [21] $\mathrm{I} \mathrm{mol}^{-1} \mathrm{~cm}^{-1}$ for trans vinylene units) and at $720 \mathrm{~cm}^{-1}$ (molar absorptivity of $60 \mathrm{I} \mathrm{mol}^{-1} \mathrm{~cm}^{-1}$ for cyclohexene/cis vinylene units [18]). Their initial concentration determined from these bands is about $4 \mathrm{~mol} \mathrm{I}^{-1}$. It means that half of the double bonds initially present in the monomer are consumed during polymerization and thermal crosslinking $[9,11]$. The remaining double bonds disappear during oxidation (Figure 3) presumably through radical additions.

3. Build-up of stable oxidation products

The changes of IR spectra (Figure 5) display several common features with those of other hydrocarbon polymers i.e.:

- a growth of a $\mathrm{H}$ bonded hydroxyl band at c.a. $3400 \mathrm{~cm}^{-1}$, 
- a complex carbonyl band in the $1650-1750 \mathrm{~cm}^{-1}$ region, the absorptions below $1700 \mathrm{~cm}^{-1}$ indicating the presence of conjugated carbonyls coming from highly oxidizable allylic carbons.

- a wide band resulting from the overlapping of several -O-C- vibrations belonging to hydroxyls, peroxides and carboxyls in the $1000-1300 \mathrm{~cm}^{-1}$ region.

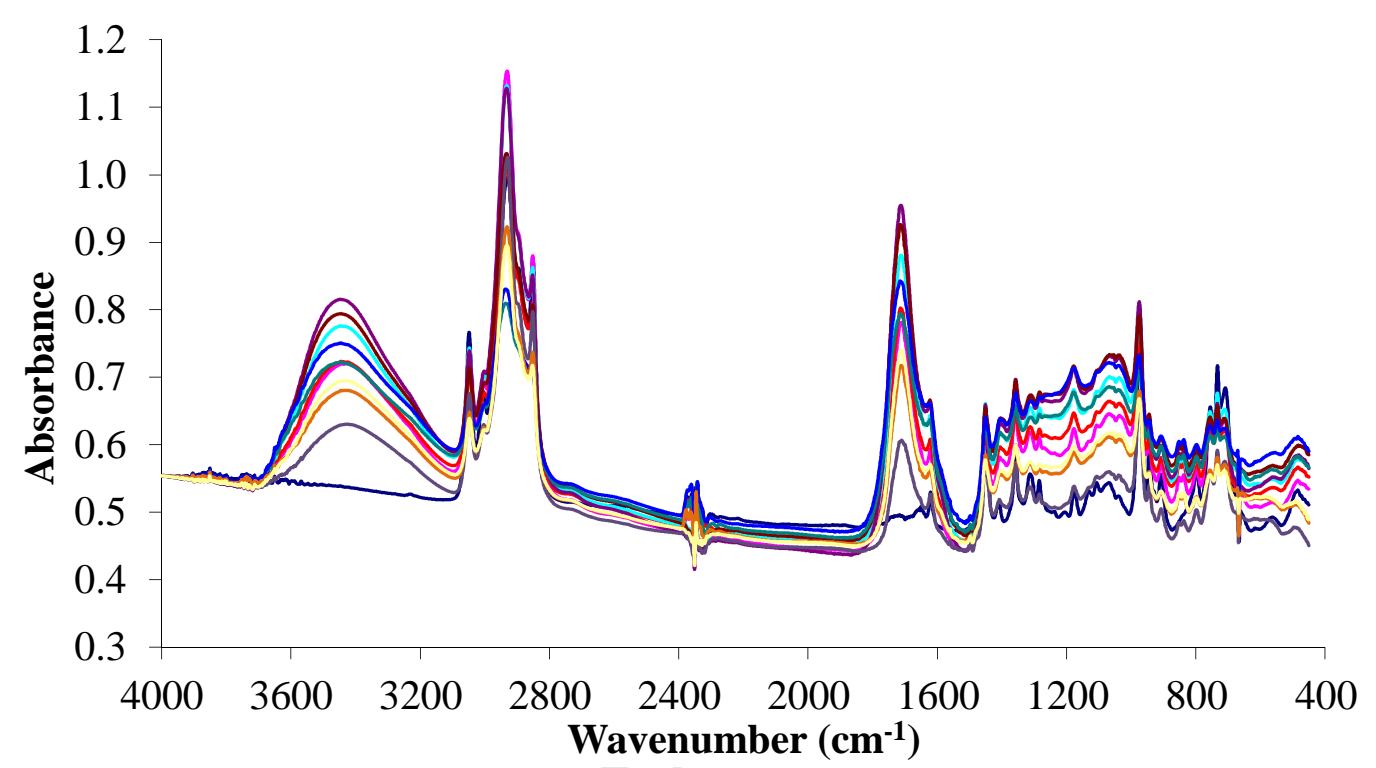

Figure 5. Changes of FTIR spectra of PDCPD exposed at $120^{\circ} \mathrm{C}$ under air ( 75 min maximal duration).

Carbonyl and hydroxyl absorbances were converted into concentrations using Beer Lambert's law with $\varepsilon_{\mathrm{CO}}=300$ and $\varepsilon_{\mathrm{OH}}=70 \mathrm{I} \mathrm{mol}^{-1} \mathrm{~cm}^{-1}[13]$. Ammonia treatments were also used for converting acids into ammonium carboxylates $\left(1550 \mathrm{~cm}^{-1}\right)$ and esters into amides $\left(1650\right.$ and $\left.3200 \mathrm{~cm}^{-1}\right)$ [22]. The simultaneous formation of ketones, carboxylic acids and esters (Figure 6) suggests the existence of a "co-oxidation" mechanism in which:

- the formation of esters and carboxylic acids is ascribed to the oxidation of secondary carbons:<smiles>[R1]C([R1])[R]</smiles> 
- the formation of ketones is ascribed to the oxidation of tertiary allylic hydrogens:

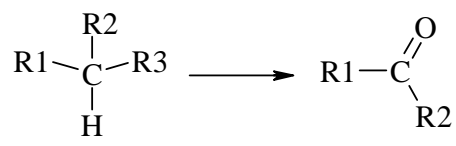

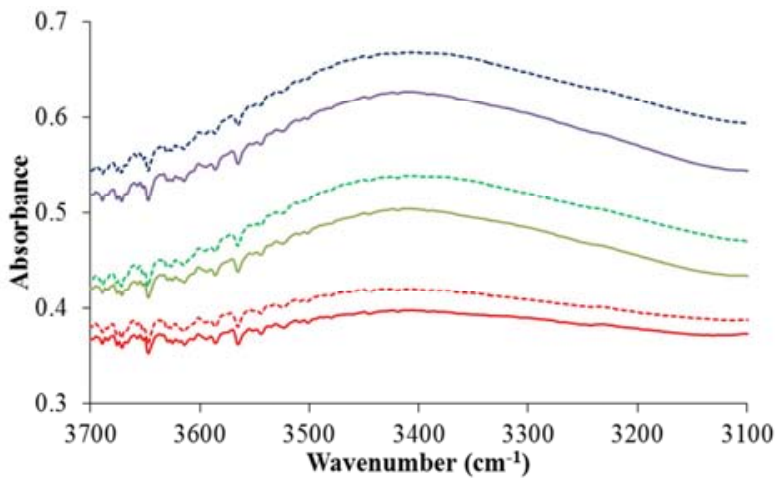

(a)

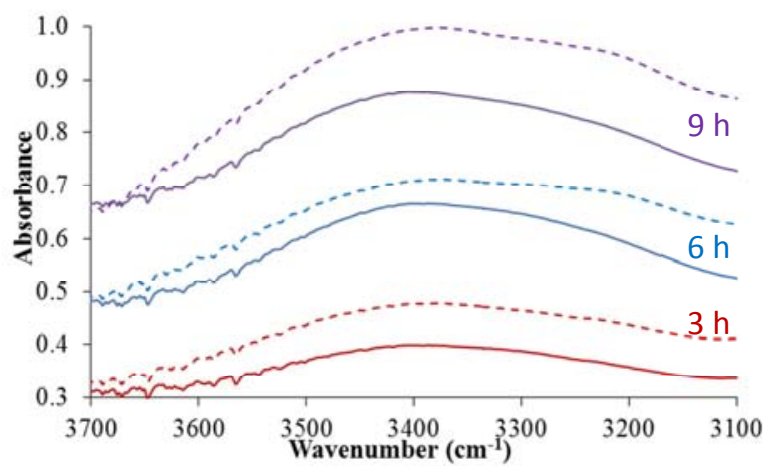

(c)

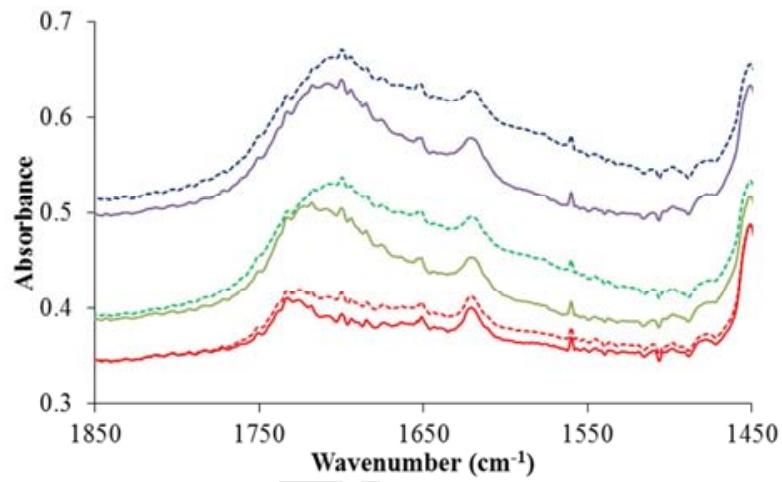

(b)

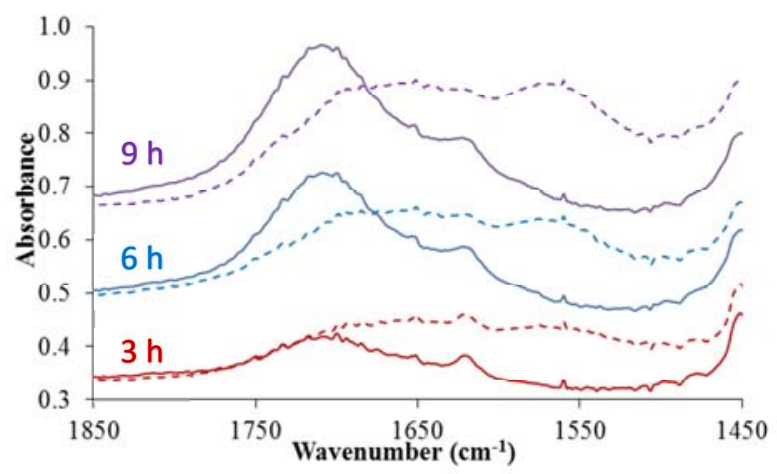

(d)

Figure 6. Effect of $\mathrm{NH}_{3}$ treatment (full lines : before, dashed lines : after) for pDCPD exposed at $120^{\circ} \mathrm{C}$ $(a, b)$ and $55^{\circ} \mathrm{C}(\mathrm{c}, \mathrm{d})$ under air.

The plot of the carbonyl concentration against hydroxyl one (Figure 7) shows that both concentrations are almost proportional. The proportionality ratio is almost temperature independent except at $30^{\circ} \mathrm{C}$ where it is significantly lower than at higher temperatures. 


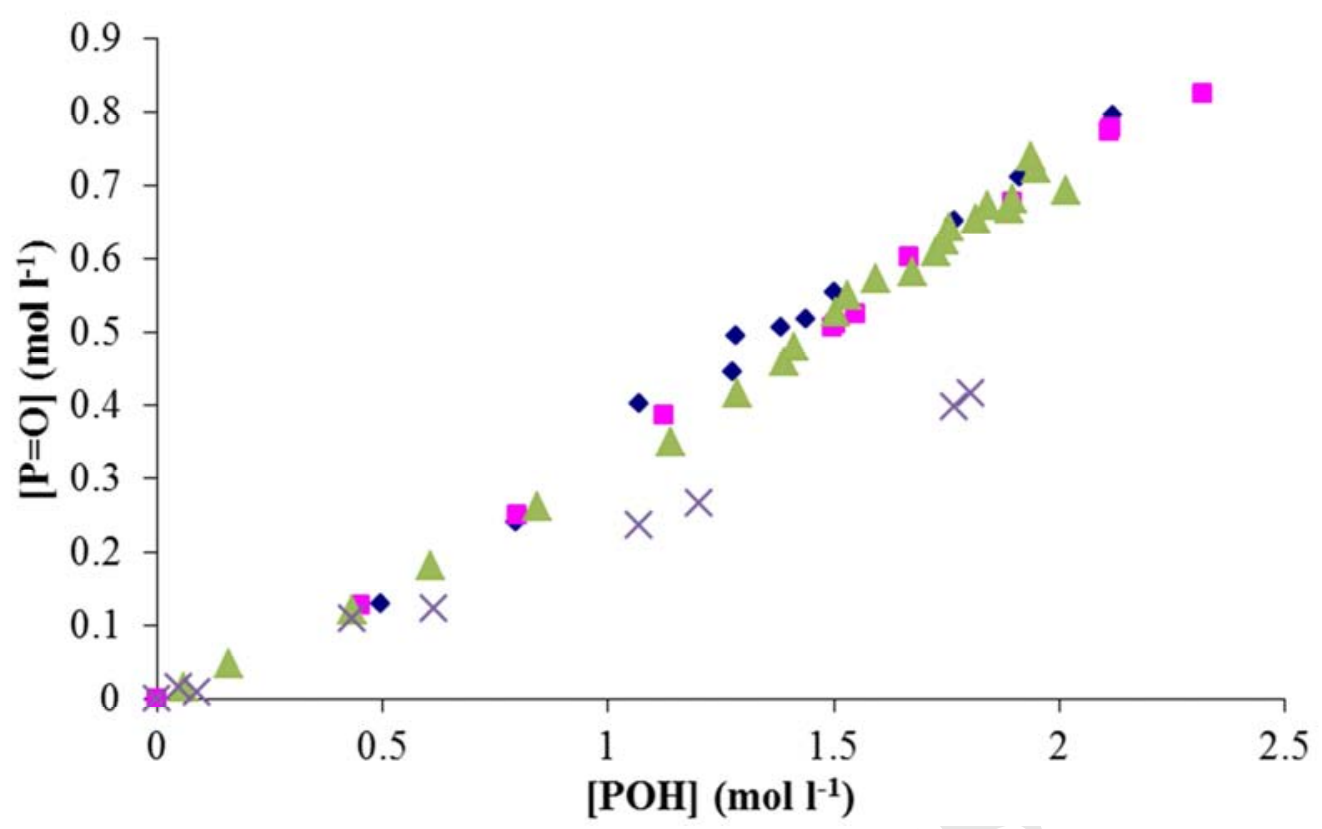

Figure 7. Plot of total carbonyl concentration versus total hydroxyl one at $120(\bullet), 90(\square), 55(\mathbf{A})$ and $30^{\circ} \mathrm{C}(\times)$. 


\section{DISCUSSION}

The aim of this section is to answer to the following questions:

- Can kinetic analysis allow understanding if the higher pDCPD oxidizability than polybutadiene and polyisoprene ones is due to a faster initiation or propagation in PDCPD than in polydienes or slower termination in PDCPD than in polydienes or, indeed, a combination of both causes?

- Why acids and esters, which are in principle secondary products, predominate over ketones at low temperature while ketones are largely predominant at $120^{\circ} \mathrm{C}$ ?

1. Kinetic analysis of PDCPD oxidation

The following mechanistic scheme will be used for describing the oxidation of pDCPD:

(1u) $\mathrm{POOH} \rightarrow 2 \mathrm{P}^{\circ}+\gamma_{\mathrm{CO}} \cdot \mathrm{P}=\mathrm{O} \quad\left(\mathrm{k}_{1 \mathrm{u}}\right)$

(1b) $2 \mathrm{POOH} \rightarrow \mathrm{P}^{\circ}+\mathrm{POO}^{\circ}+\gamma_{\mathrm{CO}} \cdot \mathrm{P}=\mathrm{O} \quad\left(\mathrm{k}_{1 \mathrm{~b}}\right)$

(2) $\mathrm{P}^{\circ}+\mathrm{O}_{2} \rightarrow \mathrm{POO}^{\circ} \quad\left(\mathrm{k}_{2}\right)$

(3) $\mathrm{POO}^{\circ}+\mathrm{PH} \rightarrow \mathrm{POOH}+\mathrm{P}^{\circ} \quad\left(\mathrm{k}_{3}\right)$

(4) $\mathrm{P}^{\circ}+\mathrm{P}^{\circ} \rightarrow$ inactive product $\quad\left(\mathrm{k}_{4}\right)$

(5) $\mathrm{P}^{\circ}+\mathrm{POO}^{\circ} \rightarrow$ inactive product $\quad\left(\mathrm{k}_{5}\right)$

(6) $\mathrm{POO}^{\circ}+\mathrm{POO}^{\circ} \rightarrow$ inactive product $\quad\left(\mathrm{k}_{6}\right)$ 
The above presented model is, no doubt, a simplification for at least two reasons:

(1) The participation of secondary and tertiary allylic carbons, in a co-oxidation mechanism (according to the results of $\mathrm{NH}_{3}$ treatments) is not envisaged.

(2) The possible radical addition to double bonds is neglected.

The oxidation rate is a hyperbolic function of oxygen concentration (this latter being proportional to oxygen pressure $p)[23]$ :

$$
r_{o x}=\frac{\alpha \cdot S \cdot p}{1+\beta \cdot S \cdot p}
$$

Where $S$ is the coefficient of oxygen solubility in the polymer, $\alpha=k_{2} \cdot\left(r_{i} / k_{4}\right)^{1 / 2}$ and $\beta=$ $\left(k_{2} / k_{3}[P H]\right) \cdot\left(k_{6} / k_{4}\right)^{1 / 2}$.

Here, the fact that $r_{o x}$ is almost proportional to oxygen pressure (Table 1 ) indicates that $\beta . S . p \ll 1$. The orders of magnitude for air at atmospheric pressure and about $100^{\circ} \mathrm{C}$ are: $k_{2} \cdot S \cdot p \sim 10^{4}-10^{5} \mathrm{~s}^{-1}$ and $k_{3}[\mathrm{PH}]=10-100 \mathrm{~s}^{-1}$. Thus the above inequality involves that $\left(\mathrm{k}_{6} / \mathrm{k}_{4}\right)^{1 / 2} \ll 10^{-4}$ to $10^{-2}$ which provides a first constraint for the determination of rate constants.

In order to gain better insights in the pDCPD oxidative behavior, four sets of simulations runs (Figure 8) were performed. The mechanistic scheme leads to a differential system (see APPENDIX B for 
example) which is numerically solved to give $\left[\mathrm{P}^{\circ}\right],\left[\mathrm{POO}^{\circ}\right],[\mathrm{POOH}]$ or $[\mathrm{P}=0]$ concentrations $[1-4]$. Underlying assumptions are:

$-k_{2}, k_{3}, k_{4}, k_{5}$ and oxygen solubility $S$ directly come from previous butadiene rubber (only secondary allylic hydrogens react) or polyisoprene (only tertiary allylic hydrogens react) $[1,2,17]$. Then, $k_{1 u}, k_{1 b}$, and $\mathrm{k}_{6}$ remain the only adjustable parameters.

- Initiation is purely uni- or bimolecular, having in mind that it actually lies between the two.

- $[\mathrm{PH}]_{0}$ is equal to twice the concentration in double bonds (determined from FTIR), $[\mathrm{POOH}]_{0}=10^{-1}$ $\mathrm{mol}^{-1}$ (from the initial value of the exothermal signal measured by DSC for virgin sample).

Hence, each simulation is characterized by a couple $k_{1 u}$ or $k_{1 b}, k_{6}$ which will be compared with polybutadiene or polyisoprene for explaining the difference in oxidizability between PDCPD and those two polymers. 


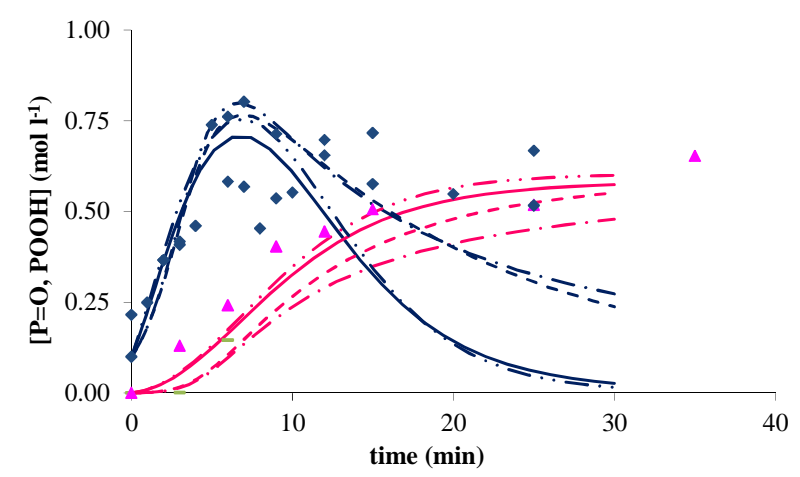

(a)

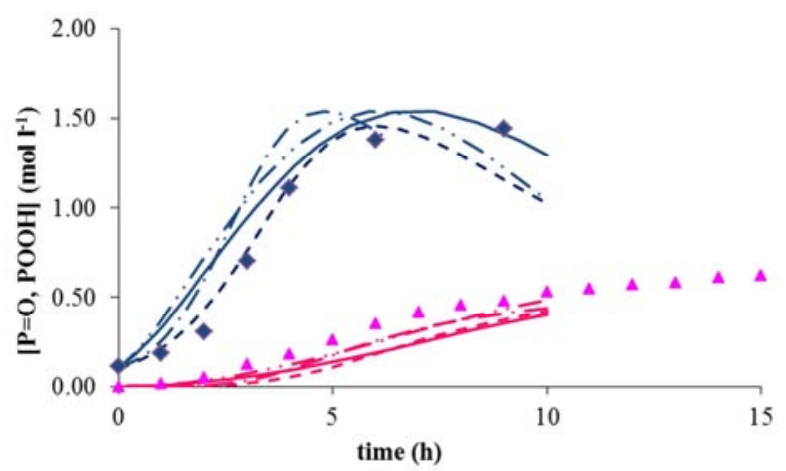

(c)

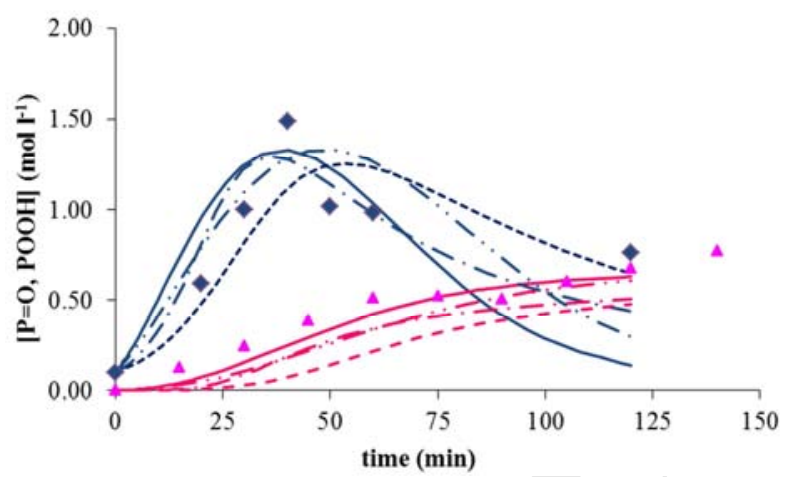

(b)

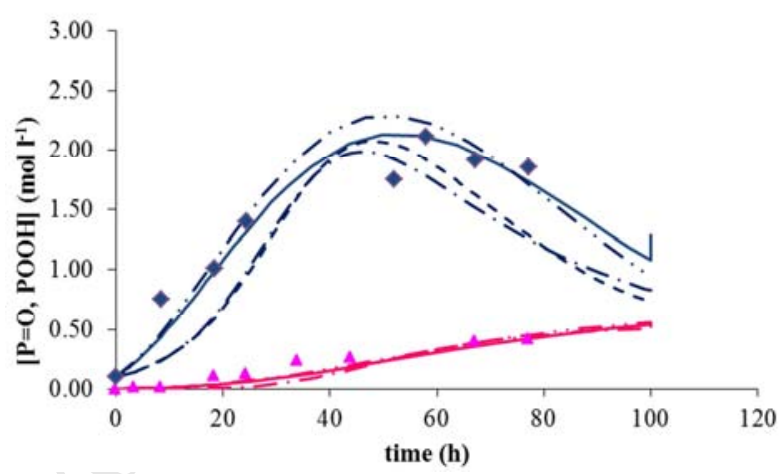

(d)

Figure 8. Simulation runs for carbonyl $(\mathrm{P}=\mathrm{O})$ and hydroperoxides $(\mathrm{POOH})$ at $120^{\circ} \mathrm{C}(\mathrm{a}), 90^{\circ} \mathrm{C}(\mathrm{b}), 55^{\circ} \mathrm{C}$ (c) and $30^{\circ} \mathrm{C}(\mathrm{d})$, in the case of allylic secondary hydrogens, unimolecular mode $(\longrightarrow)$, allylic secondary hydrogens, bimolecular mode ( $\left.--\_\right)$, allylic tertiary hydrogens, unimolecular mode (- - -), allylic tertiary hydrogens, bimolecular mode (- - - -).

The rate constants $k_{1 u}, k_{1 b}$ and $k_{6}$ coming from each simulation are recalled in Table 3. 
ACCEPTED MANUSCRIPT

\begin{tabular}{|c|c|c|c|c|c|c|c|c|}
\hline \multirow{2}{*}{$\mathbf{T}\left({ }^{\circ} \mathbf{C}\right)$} & \multicolumn{2}{|c|}{$>\mathbf{C H}_{\mathbf{2}} \mathbf{u n i}$} & \multicolumn{2}{c|}{$>\mathbf{C H}_{\mathbf{2}} \mathbf{b i}$} & \multicolumn{2}{c|}{$>\mathbf{C H}-\mathbf{u n i}$} & \multicolumn{2}{c|}{$>\mathbf{C H}-\mathbf{b i}$} \\
\hline 28 & $\mathbf{k}_{1 \mathbf{u}}$ & $\mathbf{k}_{\mathbf{6}}$ & $\mathbf{k}_{1 \mathbf{b}}$ & $\mathbf{k}_{\mathbf{6}}$ & $\mathbf{k}_{1 \mathbf{u}}$ & $\mathbf{k}_{\mathbf{6}}$ & $\mathbf{k}_{1 \mathbf{b}}$ & $\mathbf{k}_{\mathbf{6}}$ \\
\hline 55 & $5.0 \mathrm{E}-06$ & $5.0 \mathrm{E}+00$ & $4.0 \mathrm{E}-06$ & $1.0 \mathrm{E}+00$ & $5.0 \mathrm{E}-06$ & $2.5 \mathrm{E}+02$ & $4.0 \mathrm{E}-06$ & $1.0 \mathrm{E}+00$ \\
\hline 90 & $5.0 \mathrm{E}-05$ & $4.0 \mathrm{E}+02$ & $5.0 \mathrm{E}-05$ & $1.0 \mathrm{E}+02$ & $6.0 \mathrm{E}-05$ & $5.0 \mathrm{E}+03$ & $5.0 \mathrm{E}-05$ & $7.5 \mathrm{E}+02$ \\
\hline 120 & $6.0 \mathrm{E}-04$ & $2.5 \mathrm{E}+03$ & $5.0 \mathrm{E}-04$ & $1.0 \mathrm{E}+03$ & $5.0 \mathrm{E}-04$ & $7.0 \mathrm{E}+04$ & $4.0 \mathrm{E}-04$ & $2.0 \mathrm{E}+04$ \\
\hline $\mathrm{E}_{\mathrm{a}}\left(\mathrm{kJ} \mathrm{mol}{ }^{-1}\right)$ & $5.0 \mathrm{E}-03$ & $4.0 \mathrm{E}+04$ & $5.0 \mathrm{E}-03$ & $1.5 \mathrm{E}+04$ & $5.0 \mathrm{E}-03$ & $2.0 \mathrm{E}+05$ & $6.0 \mathrm{E}-03$ & $4.0 \mathrm{E}+04$ \\
\hline $\mathrm{R}^{2}$ & 73.3 & 91.0 & 74.8 & 98.6 & 72.0 & 80.7 & 75.5 & 112.8 \\
\hline
\end{tabular}

Table 3. Rate constants $\left(k_{1 \mathrm{u}}\right.$ in s $\mathrm{s}^{-1}, \mathrm{k}_{1 \mathrm{~b}}$ and $\mathrm{k}_{6}$ in $\left.\mathrm{mol}^{-1} \mathrm{~s}^{-1}\right)$ used for simulations given in Figure 8 .

They call for the following comments:

- The carbonyl yield $\gamma_{c o}$ was found in each case equal to 0.2 . It seems that this apparent yield does not depend on temperature, consistently with results presented in Figure 7.

- It is easy to verify that all $k_{1 u}$ and $k_{1 b}$ values are considerably higher than those obtain in other hydrocarbon polymers [1-4].

$-k_{6}$ is on the contrary extremely low particularly in comparison with polyisoprene and polybutadiene. The condition $k_{4}>k_{6}$ (see APPENDIX A) is fulfilled $\left(k_{4}>10^{8} \mathrm{I} \mathrm{mol}^{-1} \mathrm{~s}^{-1}\right.$ in each case). Its activation energy value is dramatically higher than model hydrocarbons $[24,25]$.

- In comparison with existing literature [1-4], the activation energy for initiation is relatively low whereas the termination one is relatively high. The correlation coefficient for Arrhenius plot is satisfying in the case of initiation, less for termination. However, if termination would be a diffusion controlled process (see below), its rate constant would not be a genuine constant anymore, i.e. that it would not necessarily obey Arrhenius's law.

2. Possible explanations of the high oxydability of pDCPD 
According to kinetic analysis, two reasons can explain the relatively fast oxidation of pDCPD:

- The extremely high value of initiation rate constants, irrespectively of the initiation mode.

- The very low rate constant value for the termination reaction between two $\mathrm{POO}^{\circ}$.

A third possible reason will be envisaged: since the oxidation rate is mainly characterized by the ratio $k_{3}^{2} / k_{6}$, several sets of $\left(k_{3}, k_{6}\right)$ could lead to comparable simulations. Hence, sets with $k_{3}$ schematically 10 times higher than above reported values would be acceptable provided that $k_{6}$ is 100 times higher (which would remain here a reasonable $k_{6}$ value). Those higher $k_{3}$ values could originate in the possibility of intramolecular reactions linked to the structure of monomeric unit (having possibly some consequences on initiation).

\subsection{Initiation}

The elevated values of $k_{1 u}$ or $k_{1 b}$ together with the low activation energy (typically $E_{1 b}>100 \mathrm{~kJ} \mathrm{~mol}^{-1}$ and $\left.\mathrm{E}_{1 \mathrm{u}}>130 \mathrm{~kJ} \mathrm{~mol}^{-1}[2-4]\right)$ suggests:

- The existence of intramolecularly favored hydroperoxides decomposition. However, such a mechanism involves an 8 members cycle.
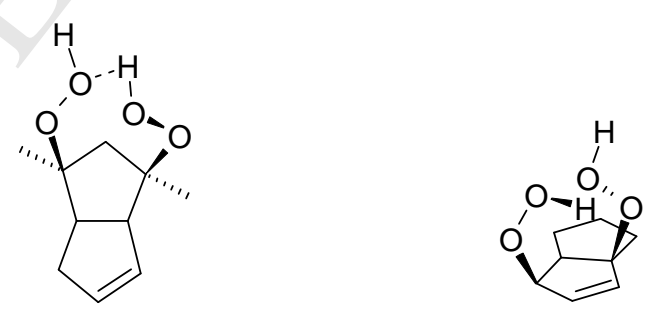

whereas the favorable configuration is a 6 membered cycle. 
- A catalyzed POOH decomposition via redox mechanisms involving the metallic catalysts $[9-11,26,27]$ or their degradation products, used in high quantity (in comparison with polyolefins [28] for polymerizing pDCPD.

\subsection{Propagation}

As previously mentioned, the structure of pDCPD could favor some intramolecular propagation step:

- by hydrogen abstraction :

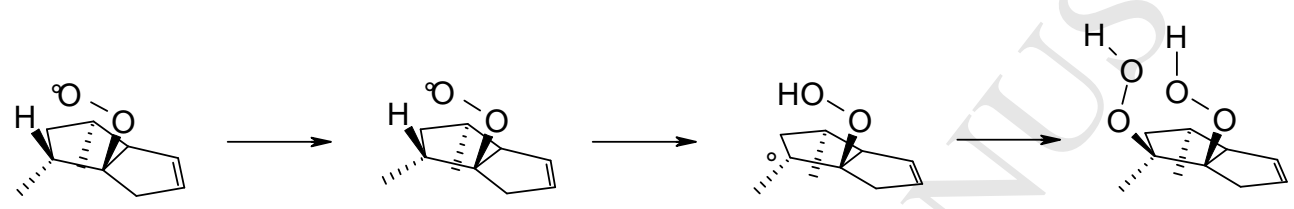

- by double bond opening:

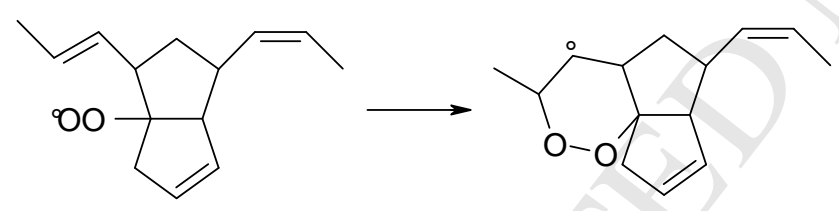

It is difficult, at this state of our knowledge, to appreciate the role of intramolecular propagation in the PDCPD oxidation. However, they are certainly favored in a glassy polymer characterized by a very low segmental mobility.

\subsection{Termination}

In polyisoprene [2] and polybutadiene [17], an efficient non terminating bimolecular combination of $\mathrm{POO}^{\circ}$ radicals competes with termination: 
(1) In the case of polyisoprene:

(6.1) $\mathrm{POO}^{\circ}+\mathrm{POO}^{\circ} \rightarrow \mathrm{POOP}+\mathrm{O}_{2}$ (terminating)

(6.2) $\mathrm{POO}^{\circ}+\mathrm{POO}^{\circ} \rightarrow 2 \mathrm{PO}^{\circ}+\mathrm{O}_{2}$ (non-terminating)

(2) In the case of polybutadiene:

(6.0) $\mathrm{POO}^{\circ}+\mathrm{POO}^{\circ} \rightarrow\left(\mathrm{PO}^{\circ} \mathrm{OP}\right)_{\text {cage }}+\mathrm{O}_{2}$ (terminating)

(6.2) $\left(\mathrm{PO}^{\circ \circ} \mathrm{OP}\right)_{\text {cage }} \rightarrow$ inactive products (terminating)

(6.3) $\left(\mathrm{PO}^{\circ} \mathrm{OP}\right)_{\text {cage }} \rightarrow 2 \mathrm{PO}^{\circ}$ (non-terminating)

In this latter case one can define an "apparent" termination rate constant (see "APPENDIX B"):

$$
k_{6 a p p}=\frac{2 k_{60} k_{61}}{k_{61}+k_{63}}
$$

We have thus compared in Table 4:

- $\mathrm{k}_{6}$ determined in this work for tertiary $\mathrm{C}-\mathrm{H}$ with $\mathrm{k}_{61}$ and $\mathrm{k}_{62}$ for polyisoprene in uni- or bimolecular mode (denoted by $>\mathrm{CH}$ - uni and $>\mathrm{CH}-$ bi),

- $\mathrm{k}_{6}$ determined in this work for secondary $\mathrm{C}-\mathrm{H}$ with $\mathrm{k}_{60}$ and $\mathrm{k}_{6 a \mathrm{pp}}$ for polybutadiene in bimolecular mode (denoted by $>\mathrm{CH}_{2}$ bi). 
ACCEPTED MANUSCRIPT

\begin{tabular}{|c|cc|c|c|c|cc|}
\hline \multirow{2}{*}{$\mathbf{T}\left({ }^{\circ} \mathbf{C}\right)$} & $>\mathbf{C H}-$ uni & $>\mathbf{C H}-\mathbf{b i}$ & \multicolumn{2}{|c|}{ polyisoprene } & \multicolumn{2}{c|}{$>\mathbf{C H}_{\mathbf{2}} \mathbf{b i}$} & \multicolumn{2}{c|}{ polybutadiene } \\
& $\mathbf{k}_{\mathbf{6}}$ & $\mathbf{k}_{\mathbf{6}}$ & $\mathbf{k}_{\mathbf{6 1}}$ & $\mathbf{k}_{\mathbf{6 2}}$ & $\mathbf{k}_{\mathbf{6}}$ & $\mathbf{k}_{\mathbf{6 0}}$ & $\mathbf{k}_{\mathbf{6 t a p p}}$ \\
\hline 28 & $2.5 \mathrm{E}+02$ & $1.0 \mathrm{E}+00$ & $1.5 \mathrm{E}+04$ & $1.1 \mathrm{E}+05$ & $1.0 \mathrm{E}+00$ & $1.7 \mathrm{E}+03$ & $2.4 \mathrm{E}+01$ \\
55 & $5.0 \mathrm{E}+03$ & $7.5 \mathrm{E}+02$ & $3.3 \mathrm{E}+04$ & $2.4 \mathrm{E}+05$ & $1.0 \mathrm{E}+02$ & $5.7 \mathrm{E}+04$ & $3.3 \mathrm{E}+02$ \\
90 & $7.0 \mathrm{E}+04$ & $2.0 \mathrm{E}+04$ & $7.4 \mathrm{E}+04$ & $5.4 \mathrm{E}+05$ & $1.0 \mathrm{E}+03$ & $1.7 \mathrm{E}+06$ & $4.0 \mathrm{E}+03$ \\
\hline 120 & $2.0 \mathrm{E}+05$ & $4.0 \mathrm{E}+04$ & $1.3 \mathrm{E}+05$ & $9.7 \mathrm{E}+05$ & $1.5 \mathrm{E}+04$ & $1.9 \mathrm{E}+07$ & $2.4 \mathrm{E}+04$ \\
\hline
\end{tabular}

Table 4. Termination rate constants of pDCPD (this work) and literature data $[2,17]$.

The termination rate constant in PDCPD is lower by several orders of magnitude than polyisoprene and polybutadiene ones. The difference is dramatic at low temperature but becomes negligible when approaching the glass transition.

Several authors $[5,6,29,30,31-33]$ have proposed that the rate constant of processes involving species in low concentrations can be expressed as a function of the rate at which species actually react together and the rate at which they diffuse in the medium. According to Waite $[5,6]$, the reactive species (here macroradicals $\mathrm{POO}^{\circ}$ ) diffuse through the medium and the reaction occurs when the distance between both reactive species become lower than a value $r_{0}$ which will be called the "cage radius". The reaction rate would be:

$$
\frac{\mathrm{dc}}{\mathrm{dt}}=-\mathrm{k}_{\mathrm{app}} \cdot \mathrm{c}^{2}=-\mathrm{k} \cdot\left(1+\frac{\mathrm{r}_{0}}{\sqrt{\pi \mathrm{Dt}}}\right) \cdot \mathrm{c}^{2}
$$

Where:

$-k=4 \pi r_{0} N_{A} D$,

$-r_{0}$ is the cage radius,

- $D$ is the radical diffusion coefficient. 
This equation was applied in the case of bimolecular quenching of excited species in initial concentration $c_{0}[31,32]$ that are not regenerated. It fails then for thermal ageing case where $\mathrm{POO}^{\circ}$ are continuously produced. Hence, Verdu [33] has recently adapted this theory:

$$
k_{6}=k_{D}\left[1+\frac{1}{-1+\left(\frac{1}{V_{C}\left[\mathrm{POO}^{\circ}\right]}+\frac{2 k_{D}}{k_{R}-k_{D}}\right)^{\frac{1}{2}}}\right]
$$

With :

$k_{D}=4 \pi r_{0} N_{A} D$

$\mathrm{V}_{\mathrm{c}}^{-1}=\left(4 \mathrm{~N}_{\mathrm{A}} \mathrm{r}_{0}^{3}\right)^{-1}$

Simulations were run using $k_{R}=k_{62}$, i.e. supposing that the upper limit $k_{R}$ value in PDCPD for the terminating $\mathrm{POO}^{\circ}+\mathrm{POO}^{\circ}$ combination in a medium of high mobility where is equal to $\mathrm{k}_{62}$ for polyisoprene. Using a typical value of $r_{0}=10^{-9} \mathrm{~m}$ [34], curves were acceptably simulated using the $D$ values reported in Table 5.

\begin{tabular}{|c|c|c|}
\hline $\mathbf{T}$ & uni & bi \\
\hline 120 & $5.0 \mathrm{E}-11$ & $5.0 \mathrm{E}-12$ \\
\hline 90 & $7.0 \mathrm{E}-12$ & $1.0 \mathrm{E}-12$ \\
\hline 55 & $6.0 \mathrm{E}-13$ & $5.0 \mathrm{E}-14$ \\
\hline 28 & $3.0 \mathrm{E}-14$ & $1.0 \mathrm{E}-15$ \\
\hline
\end{tabular}

Table 5. POO ${ }^{\circ}$ diffusivity $\mathrm{D}\left(\mathrm{m}^{2} \mathrm{~s}^{-1}\right)$ derived from $\mathrm{k}_{6}$.

It calls for the following comments: 
- At this state of our knowledge, $r_{0}$ appears as an adjustable parameter while $D$ value calculated from inverse method depends on $r_{0}$ value. For example, if $r_{0}$ is increased from 1 to $5 \mathrm{~nm}$, $D$ is almost divided by a factor 2 .

- The apparent activation energy for $D$ would be almost the same than for $k_{6}$ i.e. about $80 \mathrm{~kJ} \mathrm{~mol}^{-1}$ (Table 3).

- D is here considerably higher than values reported for PMMA [34] and for epoxy [32]. D values are actually the minimal values below which the model turns to be insensitive to this parameter, i.e. that they might be an overestimation. To avoid this complication linked to the predominance of termination 5 , it would have been necessary to study oxidation in oxygen excess regime i.e. under an oxygen pressure high enough to suppress terminations involving $\mathrm{P}^{\circ}$ radicals and to have only $\mathrm{POO}^{\circ}+$ $\mathrm{POO}^{\circ}$ termination [4]. In conclusion, the kinetic analysis of our data militates in favor of diffusion controlled termination kinetics for explaining the fast oxidation of pDCPD but supplementary data are required before definitively concluding.

3. On the nature of carbonyl species generated in PDCPD oxidation

The ratio ketones / carboxylic acids increases with temperature (Figure 6) identically to recently observed in butyl elastomer [35]. It seems paradoxical since carboxylic acids may result from the transformation of unstable aldehydes. Some possible reasons are:

(1) A competition between two modes of alkoxyl $\left(\mathrm{PO}^{\circ}\right)$ reactions i.e. disproportionation giving a ketone and $\beta$ scission giving an aldehyde: 


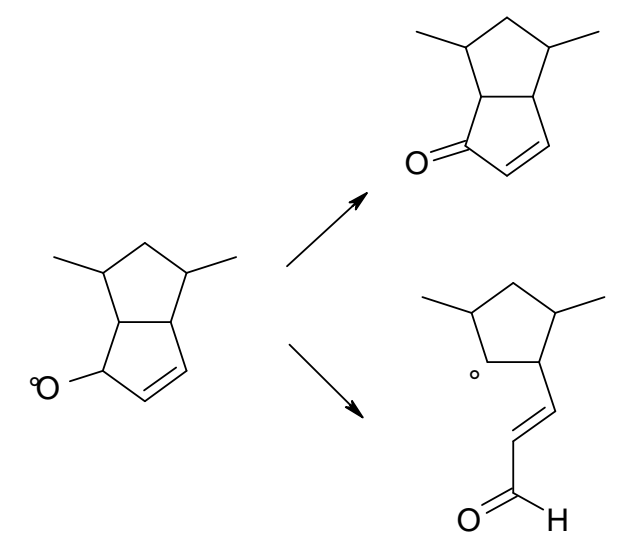

(2) A direct consequence of kinetic parameters values linked to the physical state of polymer. The processes responsible for aldehydes $(\mathrm{A})$ or ketones $(\mathrm{K})$ formation are :

- initiation events i.e. uni- or bimolecular decomposition of secondary or tertiary $\mathrm{POOH}$ denoted by $\mathrm{P}_{\mathrm{S}} \mathrm{OOH}$ or $\mathrm{P}_{\mathrm{T}} \mathrm{OOH}$ :

$$
\begin{aligned}
& \mathrm{P}_{\mathrm{S}} \mathrm{OOH} \rightarrow \mathrm{P}_{\mathrm{S}} \mathrm{O}^{\circ}+\mathrm{HO}^{\circ} \rightarrow \mathrm{P}=\mathrm{O}_{\mathrm{A}} \text { (aldehyde) } \rightarrow \text { carboxylic acid } \\
& \mathrm{P}_{\mathrm{T}} \mathrm{OOH} \rightarrow \mathrm{P}_{\mathrm{T}} \mathrm{O}^{\circ}+\mathrm{HO}^{\circ} \rightarrow \mathrm{P}=\mathrm{O}_{\mathrm{K}} \text { (ketone) } \\
& \mathrm{P}_{\mathrm{S}} \mathrm{OOH}+\mathrm{P}_{\mathrm{S}} \mathrm{OOH} \rightarrow \mathrm{P}_{\mathrm{S}} \mathrm{OO}^{\circ}+\mathrm{H}_{2} \mathrm{O}+\mathrm{P}_{\mathrm{S}} \mathrm{O}^{\circ} \rightarrow \mathrm{P}=\mathrm{O}_{\mathrm{A}} \rightarrow \text { carboxylic acid } \\
& \mathrm{P}_{\mathrm{T}} \mathrm{OOH}+\mathrm{P}_{\mathrm{T}} \mathrm{OOH} \rightarrow \mathrm{P}_{\mathrm{T}} \mathrm{OO}^{\circ}+\mathrm{H}_{2} \mathrm{O}+\mathrm{P}_{\mathrm{T}} \mathrm{O}^{\circ} \rightarrow \mathrm{P}=\mathrm{O}_{\mathrm{K}} \\
& \mathrm{P}_{\mathrm{T}} \mathrm{OOH}+\mathrm{P}_{\mathrm{S}} \mathrm{OOH} \rightarrow \mathrm{P}_{\mathrm{T}} \mathrm{OO}^{\circ}+\mathrm{H}_{2} \mathrm{O}+\mathrm{P}_{\mathrm{S}} \mathrm{O}^{\circ} \rightarrow \mathrm{P}=\mathrm{O}_{\mathrm{A}} \rightarrow \text { carboxylic acid } \\
& \mathrm{P}_{\mathrm{S}} \mathrm{OOH}+\mathrm{P}_{\mathrm{T}} \mathrm{OOH} \rightarrow \mathrm{P}_{\mathrm{S}} \mathrm{OO}^{\circ}+\mathrm{H}_{2} \mathrm{O}+\mathrm{P}_{\mathrm{T}} \mathrm{O}^{\circ} \rightarrow \mathrm{P}=\mathrm{O}_{\mathrm{K}}
\end{aligned}
$$


- termination events resulting from the combination of two $\mathrm{POO}^{\circ}$, giving an unstable tetroxyde POOOOP which quasi-instantaneously decomposes into "caged" alkoxy radicals $\mathrm{PO}^{\circ}$. Then, three routes are theoretically possible :

$$
\begin{aligned}
& \text { Formation of dialkyl peroxide }:\left[\mathrm{PO}^{\circ}+\mathrm{PO}^{\circ}\right]_{\text {cage }} \rightarrow \mathrm{POOP} \\
& \text { Disproportionation : }\left[\mathrm{PO}^{\circ}+\mathrm{PO}^{\circ}\right]_{\text {cage }} \rightarrow \mathrm{POH}+\mathrm{P}=\mathrm{O}
\end{aligned}
$$

Escape from the cage with $\beta$ scission of alkoxyls : $\left[\mathrm{PO}^{\circ}+\mathrm{PO}^{\circ}\right]_{\text {cage }} \rightarrow 2 \mathrm{PO}^{\circ} \rightarrow 2 \mathrm{P}^{\circ}+2 \mathrm{P}=0$

If escape from the cage is negligible because of the above evoked low segmental mobility, then the disproportionation will be the unique source of ketones:

$$
\begin{aligned}
& {\left[\mathrm{P}_{\mathrm{S}} \mathrm{O}^{\circ}+\mathrm{P}_{\mathrm{S}} \mathrm{O}^{\circ}\right]_{\text {cage }} \rightarrow \mathrm{P}_{\mathrm{S}} \mathrm{OH}+\mathrm{P}=\mathrm{O}_{\mathrm{K}}} \\
& {\left[\mathrm{P}_{\mathrm{S}} \mathrm{O}^{\circ}+\mathrm{P}_{\mathrm{T}} \mathrm{O}^{\circ}\right]_{\text {cage }} \rightarrow \mathrm{P}_{\mathrm{T}} \mathrm{OH}+\mathrm{P}=\mathrm{O}_{\mathrm{K}}} \\
& {\left[\mathrm{P}_{\mathrm{T}} \mathrm{O}^{\circ}+\mathrm{P}_{\mathrm{T}} \mathrm{O}^{\circ}\right]_{\text {cage }} \text { disproportionation is impossible (no abstractable hydrogen atom). }}
\end{aligned}
$$

Then:

- Initiation events generate both ketones and aldehydes (and then carboxylic acids).

- Termination by $\mathrm{POO}^{\circ}+\mathrm{POO}^{\circ}$ termination events generates rather ketones.

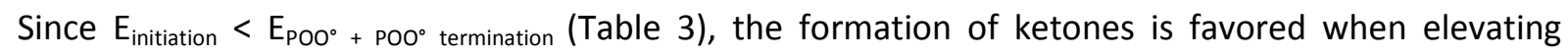
temperature and carboxylic acids is favored when lowering temperatures, consistently with the exploitation of $\mathrm{NH}_{3}$ treatments results given in Figure 6. 


\section{CONCLUSIONS}

Polycyclopentadiene oxidation was studied in glassy state by using FITR spectroscopy, chemical derivatization treatments $\left(\mathrm{NH}_{3}, \mathrm{SO}_{2}\right)$, hydroperoxides titration by DSC and iodometry, mass changes by TGA under several oxygen partial pressures. The comparison of PDCPD oxidation kinetics with polybutadiene and polyisoprene ones showed that PDCPD oxidized faster despite a lower concentration of double bonds. A kinetic model was used to describe oxidation kinetics, corresponding rate constants were determined from the shape of the curves. Their values were compared with those of polybutadiene and polyisoprene in order to explain high oxidizability of pDCPD: $\mathrm{pDCPD}$ has higher initiation rate constants, possibly ascribed to a higher concentration of metallic catalyst residues, and lower termination constants that could be due to lower segmental mobility responsible for a diffusion control of bimolecular reactions between $\mathrm{POO}^{\circ}$ macroradicals. Another explanation due to the peculiar structure of PDCPD favoring intramolecular processes (initiation and propagation) was also considered. 


\section{ACKNOWLEDGEMENTS}

Carnot Arts and Carnot Edrome are gratefully acknowledged for having granted this research. 


\section{APPENDIX A}

Under the assumption of long kinetic chains, it can be shown that:

$$
\frac{d m}{d t}=32 k_{2}\left[P^{\circ}\right]\left[O_{2}\right]
$$

Hence, the proportionality between rate of mass increase and $\left[\mathrm{O}_{2}\right]$ means that $\left[\mathrm{P}^{\circ}\right]$ changes with $\left[\mathrm{O}_{2}\right]$ are negligible which is a characteristic of the oxidation regime in which termination is dominated by $\mathrm{P}^{\circ}+\mathrm{POO}^{\circ}$ reaction [36]. By deriving the set of differential equations from the above scheme, and using the simplifications made by Achimsky et al. [37] it can be shown that, in the domain were the oxidation rate is almost proportional to oxygen pressure:

For the termination $\mathrm{P}^{\circ}+\mathrm{P}^{\circ}: \mathrm{r}_{4}=2 \mathrm{k}_{4}\left[\mathrm{P}^{\circ}\right]^{2}=2 \mathrm{k}_{3}{ }^{2} \mathrm{k}_{4}[\mathrm{PH}]^{2} / \mathrm{k}_{5}{ }^{2}$

For the termination $\mathrm{P}^{\circ}+\mathrm{POO}^{\circ}: \mathrm{r}_{5}=\mathrm{k}_{5}\left[\mathrm{P}^{\circ}\right]\left[\mathrm{POO}^{\circ}\right]=0.45 . \mathrm{k}_{2} \mathrm{k}_{3}[\mathrm{PH}]\left[\mathrm{O}_{2}\right] / \mathrm{k}_{5}$

For the termination $\mathrm{POO}^{\circ}+\mathrm{POO}^{\circ}: \mathrm{r}_{6}=2 \mathrm{k}_{6}\left[\mathrm{POO}^{\circ}\right]^{2}=2\left(0.45^{2} \cdot \mathrm{k}_{2}{ }^{2} \mathrm{k}_{6}\left[\mathrm{O}_{2}\right]^{2} / \mathrm{k}_{5}{ }^{2}\right)$

Here, termination is largely dominated by $\mathrm{P}^{\circ}+\mathrm{POO}^{\circ}$ combinations: $\mathrm{r}_{5} \gg \mathrm{r}_{4}$ and $\mathrm{r}_{6}$

so that: $\quad \mathrm{k}_{5} \gg>\mathrm{k}_{3}[\mathrm{PH}] / \mathrm{k}_{2}\left[\mathrm{O}_{2}\right] \times \mathrm{k}_{4}$

and: $\quad \mathrm{k}_{5} \gg \mathrm{k}_{2}\left[\mathrm{O}_{2}\right] / \mathrm{k}_{3}[\mathrm{PH}] \times \mathrm{k}_{6}$

According to the above recalled orders of magnitude: $\mathrm{k}_{3}[\mathrm{PH}] / \mathrm{k}_{2}\left[\mathrm{O}_{2}\right] \sim 10^{-4}-10^{-2}$, so that:

$$
k_{5}>>\left(10^{-4}-10^{-2}\right) \cdot k_{4}
$$




$$
k_{5}>\left(10-10^{3}\right) \cdot k_{6}
$$

In other words, the ratio $k_{5} / k_{6}$ which is higher than unity only for thermochemical reasons, is strongly increased when the diffusion control operates. 


\section{APPENDIX B}

Let us consider the following scheme for the oxygen excess regime:
$\mathrm{POOH}+\mathrm{POOH} \rightarrow \mathrm{P}^{\circ}+\mathrm{POO}^{\circ}+\mathrm{P}=\mathrm{O}$
$k_{1 b}$
$\mathrm{P}^{\circ}+\mathrm{O}_{2} \rightarrow \mathrm{POO}^{\circ}$
$\mathrm{k}_{2}$
$\mathrm{POO}^{\circ}+\mathrm{PH} \rightarrow \mathrm{POOH}+\mathrm{P}^{\circ}$
$\mathrm{k}_{3}$
$\mathrm{POO}^{\circ}+\mathrm{POO}^{\circ} \rightarrow \mathrm{POOOOP} \rightarrow\left(\mathrm{PO}^{\circ} \mathrm{OP}\right)_{\text {cage }} \quad \mathrm{k}_{60}$
$\left(\mathrm{PO}^{\circ \circ} \mathrm{OP}\right)_{\text {cage }} \rightarrow$ inactive products $\quad \mathrm{k}_{61}$
$\left(\mathrm{PO}^{\circ} \mathrm{OP}\right)_{\text {cage }} \rightarrow 2 \mathrm{PO}^{\circ} \rightarrow 2 \mathrm{P}=\mathrm{O}+2 \mathrm{P}^{\circ}$
$k_{63}$

This schemes leads to the following set of differential equations:

$$
\begin{gathered}
\frac{d\left[\mathrm{P}^{\circ}\right]}{d t}=k_{1 b}[\mathrm{POOH}]^{2}-\mathrm{k}_{2}\left[\mathrm{P}^{\circ}\right]\left[\mathrm{O}_{2}\right]+\mathrm{k}_{3}[\mathrm{POO}][\mathrm{PH}]+2 \mathrm{k}_{63}\left[\left(\mathrm{PO}^{\circ} \mathrm{OP}\right)_{\text {cage }}\right] \\
\frac{\mathrm{d}\left[\mathrm{POO}^{\circ}\right]}{\mathrm{dt}}=\mathrm{k}_{1 \mathrm{~b}}[\mathrm{POOH}]^{2}+\mathrm{k}_{2}\left[\mathrm{P}^{\circ}\right]\left[\mathrm{O}_{2}\right]-\mathrm{k}_{3}[\mathrm{POO}][\mathrm{PH}]-2 \mathrm{k}_{60}\left[\mathrm{POO}^{\circ}\right]^{2} \\
\frac{\mathrm{d}[\mathrm{POOH}]}{\mathrm{dt}}=-2 \mathrm{k}_{1 \mathrm{~b}}[\mathrm{POOH}]^{2}+\mathrm{k}_{3}[\mathrm{POO}][\mathrm{PH}] \\
\frac{\mathrm{d}\left[\left(\mathrm{PO}^{\circ} \mathrm{OP}\right)_{\text {cage }}\right]}{\mathrm{dt}}=\mathrm{k}_{60}\left[\mathrm{POO}^{\circ}\right]^{2}-\left(\mathrm{k}_{61}+\mathrm{k}_{63}\right)\left[\left(\mathrm{PO}{ }^{\circ} \mathrm{OP}\right)_{\text {cage }}\right]
\end{gathered}
$$

If the steady state approximation can be used for $\left(\mathrm{PO}{ }^{\circ} \mathrm{OP}\right)_{\text {cage }}$ : 


$$
\left[\left(\mathrm{PO}^{\circ} \mathrm{OP}\right)_{\mathrm{cage}}\right]=\frac{\mathrm{k}_{60}}{\mathrm{k}_{61}+\mathrm{k}_{63}}\left[\mathrm{POO}^{\circ}\right]^{2}
$$

Thus, by applying the steady state for $\left[\mathrm{P}^{\circ}+\mathrm{POO}^{\circ}\right]$ :

$$
2 \mathrm{k}_{1 \mathrm{~b}}[\mathrm{POOH}]^{2}=\left(2 \mathrm{k}_{60}-\frac{2 \mathrm{k}_{63} \mathrm{k}_{60}}{\mathrm{k}_{61}+\mathrm{k}_{63}}\right)\left[\mathrm{POO}^{\circ}\right]^{2}=\frac{2 \mathrm{k}_{60} \mathrm{k}_{61}}{\mathrm{k}_{61}+\mathrm{k}_{63}}\left[\mathrm{POO}^{\circ}\right]^{2}
$$

And, since in steady state:

$$
\begin{aligned}
2 \mathrm{k}_{1 b}[\mathrm{POOH}]^{2} & =\mathrm{k}_{3}\left[\mathrm{POO}^{\circ}\right][\mathrm{PH}] \\
{[\mathrm{POOH}] } & =\frac{\mathrm{k}_{3}{ }^{2}[\mathrm{PH}]^{2}}{2 \mathrm{k}_{1 b} \mathrm{k}_{6 \mathrm{app}}}
\end{aligned}
$$

With:

$$
k_{6 a p p}=\frac{2 k_{60} k_{61}}{k_{61}+k_{63}}
$$




\section{REFERENCES}

1. Coquillat M. Vieillissement des propergols à matrice polybutadiène : modélisation cinétique de l'oxydation. Thèse de l'ENSAM de Paris (2007).

2. Colin X, Audouin L, Verdu J. Kinetic modelling of the thermal oxidation of polyisoprene elastomers. Part 1: Unvulcanized unstabilized polyisoprene. Polym Degrad Stab 2007;92(5):886-897.

3. Khelidj N, Colin X, Audouin L, Verdu J, Monchy-Leroy C, Prunier V. Oxidation of polyethylene under irradiation at low temperature and low dose rate. Part II. Low temperature thermal oxidation. Polym Degrad Stab 2006;91(7):1598-1605.

4. Richaud E, Farcas F, Fayolle B, Audouin L, Verdu J. Hydroperoxide build-up in the thermal oxidation of polypropylene - A kinetic study. Polym Degrad Stab 2007;92(1):118-124.

5. Waite TR. General theory of bimolecular reaction rates in solids and liquids. J Chem Phys 1958;28(1):103106.

6. Waite TR. Theoretical treatment of the kinetics of diffusion-limited reactions. Phys Rev 1957;107(2):463-470.

7. Mayo FR. Relative reactivities in oxidations of polypropylene and polypropylene models. Macromolecules $1978 ; 11(5): 942-946$.

8. Richaud E, Ferreira P, Audouin L, Colin X, Verdu J, Monchy-Leroy C. Radiochemical ageing of poly(ether ether ketone). Eur Pol J 2010;46(4):731-743.

9. Davidson TA, Wagener KB. The polymerization of dicyclopentadiene: an investigation of mechanism. J Mol Catal A: Chem 1998;133(1-2):67-74.

10. Dimonie D, Dimonie M, Stoica S, Munteanu V, Abadie MJ. Some aspects of the thermal stability of linear polydicyclopentadiene (L-PDCPD). Polym Degrad Stab 2000;67(1):167-170.

11. Dimonie D, Dimonie M, Munteanu V, lovu H, Couve J, Abadie MJ. Nature of the first exothermic peak on the DSC curve of linear polydicyclopentadiene obtained with a special catalytic system. Polym Degrad Stab 2000;70(3):319-324 
12. Le Gac PY, Choqueuse D, Paris M, Recher G, Zimmer C, Melot D. Durability of polydicyclopentadiene under high temperature, high pressure and seawater (offshore oil production conditions). Polym Degrad Stab 2013;98(3):809-817.

13. Richaud E, Farcas F, Fayolle B, Audouin L, Verdu J. Hydroperoxide titration by DSC in thermally oxidized polypropylene. Polym Test 2006;25(6):829-838.

14. Gardette J-L, Lemaire J. Advantages and limits of hydroperoxide titration methods in solid polymers. Polym Photochem 1986;7(5):409-416.

15. Carlsson DJ, Lacoste J. A critical comparison of methods for hydroperoxide measurement in oxidized polyolefins. Polym Degrad Stab 1991;32(3):377-386.

16. Scheirs J, Carlsson DJ, Bigger SW. A Review of the Methods For Detecting and Characterizing Hydroperoxide Groups in Oxidized Polyolefins. Polym-Plast Technol 1995;34(1):97-116.

17. Coquillat M, Verdu J, Colin X, Audouin L, Nevière R. Thermal oxidation of polybutadiene. Part 1: Effect of temperature, oxygen pressure and sample thickness on the thermal oxidation of hydroxyl-terminated polybutadiene. Polym Degrad Stab 2007;92(7):1326-1333.

18. Calvert JG, Pitts JN. Photochemistry. New York: Wiley, 1966, p. 815.

19. Audouin L, Gueguen V, Tcharkhtchi A, Verdu J. 'Close loop' mechanistic schemes for hydrocarbon polymer oxidation. J Polym Sci Pol Chem 1995;33(6):921-927.

20. McMurry H, Thornton V. Correlation of infrared spectra. Anal Chem 1952;24(2):318-334.

21. Moss S, Zweifel H. Degradation and stabilization of high density polyethylene during multiple extrusions. Polym Degrad Stab 1989;25(2-4):217-245.

22. Wilhelm C, Gardette J-L. Infrared identification of carboxylic acids formed in polymer photooxidation. J Appl Polym Sci 1994;51(8):1411-1420.

23. Verdu J. Oxidative ageing of polymers. Hoboken: John Wiley \& Sons, 2012, p. 80.

24. Denisov ET, Afanas'ev IB. Oxidation and Antioxidants in Organic Chemistry and Biology. Boca Raton, London, New York, Singapore: CBC Taylor \& Francis Group, 2005, p. 59. 
25. Bennett JE, Brown DM, Mile B. Studies by electron spin resonance of the reactions of alkylperoxy radicals.

Part 1. - Absolute rate constants for the termination reactions of alkylperoxy radicals. Trans Farad Soc $1970 ; 66: 386-396$.

26. Abadie MJ, Dimonie M, Couve C, Dragutan V. New catalysts for linear polydicyclopentadiene synthesis.

Eur Pol J 2000;36(6):1213-1219.

27. Cuia H, Hanusa R, Kesslera MR. Degradation of ROMP-based bio-renewable polymers by UV radiation. Polym Degrad Stab. In press (DOI: j.polymdegradstab.2013.08.003).

28. Imuta JI, Kashiwa N. Recent Progess on single-site catalysts. In: Vasile C, editor. Handbook of Polyolefins, Second Edition, revised and explanded. New York: Marcel Dekker Inc, 2000. p. 71.

29. Begum F, Zhao H, Simon SL. Modeling methyl methacrylate free radical polymerization: Reaction in hydrophilic nanopores. Polymer 2012;53(15):3238-3244.

30. Begum F, Zhao H, Simon SL. Modeling methyl methacrylate free radical polymerization: Reaction in hydrophobic nanopores. Polymer 2012;53(15):3261-3268.

31. Martins J, Melo E. Molecular Mechanism of Lateral Diffusion of py10-PC and Free Pyrene in Fluid DMPC Bilayers. Biophys J 2001;80(2):832-840.

32. Devanne T, Bry A, Raguin N, Sebban M, Palmas P, Audouin L, Verdu J. Radiochemical ageing of an amine cured epoxy network. Part II: kinetic modeling. Polymer 2005;46(1):237-241.

33. Verdu J. Oxidative ageing of polymers. Hoboken: John Wiley \& Sons, 2012, p. 145

34. Emanuel NM, Buchachenko AL. Chemical Physics of Polymer Degradation and Stabilization (New Concepts in Polymer Science). Utrecht: VNU Science Press, 1987, p. 84.

35. Pazur RJ. Lifetime Prediction of Thermo-oxidized Copolymers of Isobutylene. In Proceedings of 30th Polymer Degradation Discussion Group. September 1-4th, 2013. Paris (France).

36. Verdu J. Oxidative ageing of polymers. Hoboken: John Wiley \& Sons, 2012, p. 95.

37. Achimsky L, Audouin L, Verdu J, Rychlá L, Rychlý J. The effect of oxygen pressure on the rate of polypropylene oxidation determined by chemiluminescence. Eur Pol J 1999;35(4):557-563. 


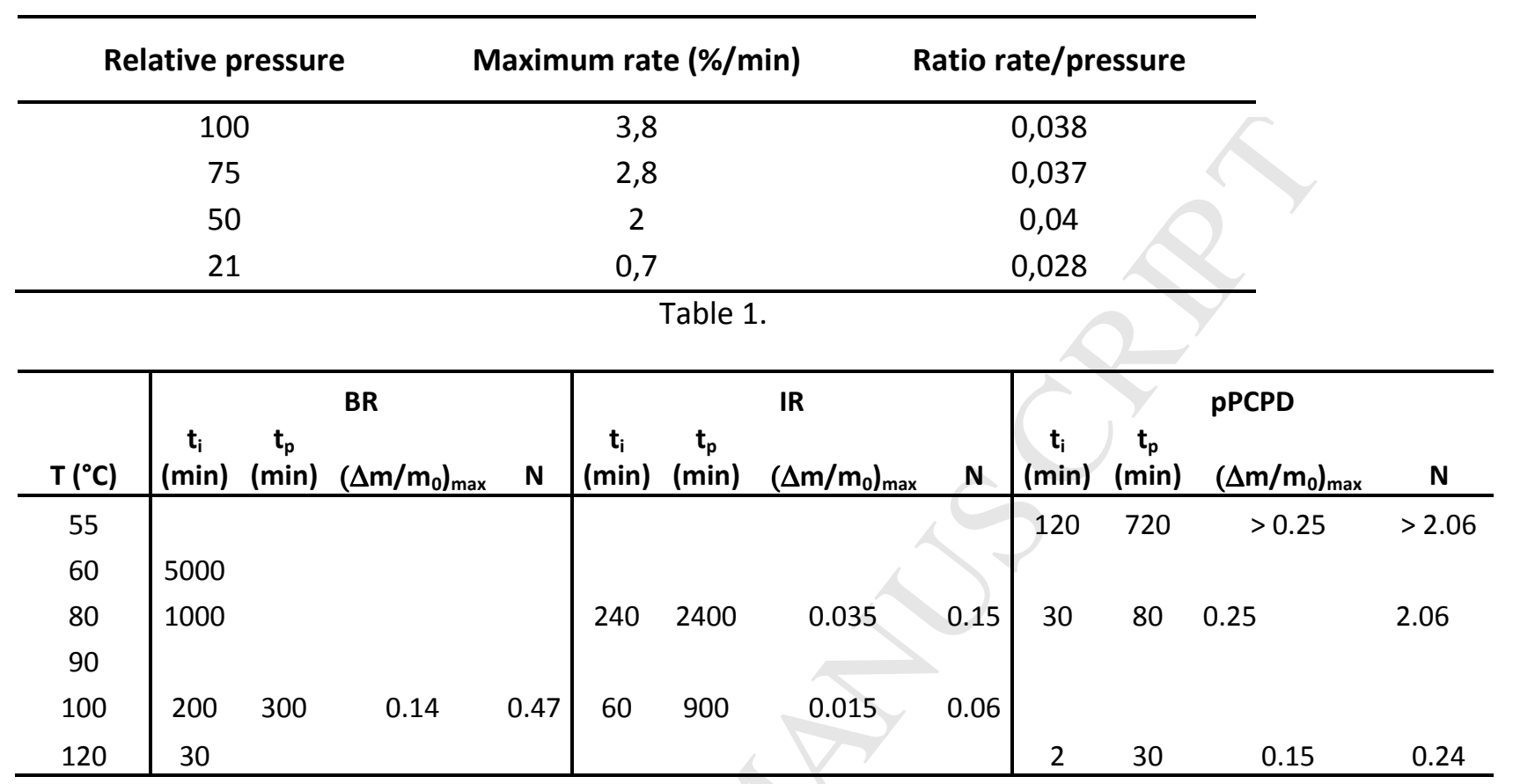

Table 2.

\begin{tabular}{|c|cc|cc|cc|cc|}
\hline \multirow{2}{*}{$\mathbf{T}\left({ }^{\circ} \mathrm{C}\right)$} & \multicolumn{2}{|c|}{$>\mathrm{CH}_{\mathbf{2}}$ uni } & \multicolumn{2}{c|}{$>\mathrm{CH}_{\mathbf{2}} \mathbf{b i}$} & \multicolumn{2}{c|}{$>\mathrm{CH}-\mathbf{u n i}$} & \multicolumn{2}{c|}{$>\mathrm{CH}-\mathbf{b i}$} \\
& $\mathbf{k}_{1 \mathrm{u}}$ & $\mathbf{k}_{\mathbf{6}}$ & $\mathbf{k}_{1 \mathrm{~b}}$ & $\mathbf{k}_{\mathbf{6}}$ & $\mathbf{k}_{1 \mathrm{u}}$ & $\mathbf{k}_{6}$ & $\mathbf{k}_{1 \mathrm{~b}}$ & $\mathbf{k}_{\mathbf{6}}$ \\
\hline 28 & $5.0 \mathrm{E}-06$ & $5.0 \mathrm{E}+00$ & $4.0 \mathrm{E}-06$ & $1.0 \mathrm{E}+00$ & $5.0 \mathrm{E}-06$ & $2.5 \mathrm{E}+02$ & $4.0 \mathrm{E}-06$ & $1.0 \mathrm{E}+00$ \\
55 & $5.0 \mathrm{E}-05$ & $4.0 \mathrm{E}+02$ & $5.0 \mathrm{E}-05$ & $1.0 \mathrm{E}+02$ & $6.0 \mathrm{E}-05$ & $5.0 \mathrm{E}+03$ & $5.0 \mathrm{E}-05$ & $7.5 \mathrm{E}+02$ \\
90 & $6.0 \mathrm{E}-04$ & $2.5 \mathrm{E}+03$ & $5.0 \mathrm{E}-04$ & $1.0 \mathrm{E}+03$ & $5.0 \mathrm{E}-04$ & $7.0 \mathrm{E}+04$ & $4.0 \mathrm{E}-04$ & $2.0 \mathrm{E}+04$ \\
120 & $5.0 \mathrm{E}-03$ & $4.0 \mathrm{E}+04$ & $5.0 \mathrm{E}-03$ & $1.5 \mathrm{E}+04$ & $5.0 \mathrm{E}-03$ & $2.0 \mathrm{E}+05$ & $6.0 \mathrm{E}-03$ & $4.0 \mathrm{E}+04$ \\
\hline $\mathrm{E}_{\mathrm{a}}\left(\mathrm{kJ} \mathrm{mol}{ }^{-1}\right)$ & 73.3 & 91.0 & 74.8 & 98.6 & 72.0 & 80.7 & 75.5 & 112.8 \\
$\mathrm{R}^{2}$ & 0.9984 & 0.9700 & 0.9965 & 0.9778 & 0.9977 & 0.9979 & 0.988 & 0.9051 \\
\hline
\end{tabular}

Table 3.

\begin{tabular}{|c|cc|cc|c|cc|}
\hline \multirow{2}{*}{$\mathbf{T}\left({ }^{\circ} \mathbf{C}\right)$} & $>\mathbf{C H}-$ uni & $>\mathbf{C H}-\mathbf{b i}$ & \multicolumn{2}{|c|}{ polyisoprene } & \multicolumn{2}{c|}{$>\mathbf{C H}_{\mathbf{2}} \mathbf{b i}$} & \multicolumn{2}{c|}{ polybutadiene } \\
& $\mathbf{k}_{\mathbf{6}}$ & $\mathbf{k}_{\mathbf{6}}$ & $\mathbf{k}_{61}$ & $\mathbf{k}_{\mathbf{6 2}}$ & $\mathbf{k}_{\mathbf{6}}$ & $\mathbf{k}_{\mathbf{6 0}}$ & $\mathbf{k}_{6 \text { tapp }}$ \\
\hline 28 & $2.5 \mathrm{E}+02$ & $1.0 \mathrm{E}+00$ & $1.5 \mathrm{E}+04$ & $1.1 \mathrm{E}+05$ & $1.0 \mathrm{E}+00$ & $1.7 \mathrm{E}+03$ & $2.4 \mathrm{E}+01$ \\
55 & $5.0 \mathrm{E}+03$ & $7.5 \mathrm{E}+02$ & $3.3 \mathrm{E}+04$ & $2.4 \mathrm{E}+05$ & $1.0 \mathrm{E}+02$ & $5.7 \mathrm{E}+04$ & $3.3 \mathrm{E}+02$ \\
90 & $7.0 \mathrm{E}+04$ & $2.0 \mathrm{E}+04$ & $7.4 \mathrm{E}+04$ & $5.4 \mathrm{E}+05$ & $1.0 \mathrm{E}+03$ & $1.7 \mathrm{E}+06$ & $4.0 \mathrm{E}+03$ \\
120 & $2.0 \mathrm{E}+05$ & $4.0 \mathrm{E}+04$ & $1.3 \mathrm{E}+05$ & $9.7 \mathrm{E}+05$ & $1.5 \mathrm{E}+04$ & $1.9 \mathrm{E}+07$ & $2.4 \mathrm{E}+04$ \\
\hline
\end{tabular}

Table 4. 


\begin{tabular}{ccc}
\hline $\mathbf{T}$ & uni & bi \\
\hline 120 & $5.0 \mathrm{E}-11$ & $5.0 \mathrm{E}-12$ \\
90 & $7.0 \mathrm{E}-12$ & $1.0 \mathrm{E}-12$ \\
55 & $6.0 \mathrm{E}-13$ & $5.0 \mathrm{E}-14$ \\
28 & $3.0 \mathrm{E}-14$ & $1.0 \mathrm{E}-15$ \\
\hline
\end{tabular}

Table 5. 